\title{
PYTANIA O MUZYKE W KOŚCIELE MARIACKIM W KRAKOWIE W PIERWSZEJ POŁOWIE XVI STULECIA I O POSTAĆ JANA Z LUBLINA
}

\begin{abstract}
Dytając dwadzieścia lat temu o muzyczną paralelę snycerskiego mistrzostwa Wita 1 Stwosza, wskazał Mirosław Perz twórczość Heinricha Fincka‥ Przypomniał przy tym przekornie jeden z poglądów Curta Sachsa, wywiedzionych z przemyśleń nad miejscem muzyki w ramach powszechnej historii sztuki - chodzi o regułę „Stellvertretung” (zastępstwa, zamiany miejsc), według której rozkwit sztuk wizualnych może się łączyć z regresem w sztuce tonów i odwrotnie ${ }^{2}$. Koncepcja już przebrzmiała, ale w pewnym sensie nadal podlega weryfikacji przy próbach oceny rangi i roli, jaką sztuka muzyczna odgrywała w ośrodkach ważnych dla dziejów kultury. Niekiedy sprawy te pozostają nie w pełni rozpoznane, co może wynikać z niedostatku źródeł stricte muzycznych. Uwaga ta dotyczy m.in. krakowskiej fary Mariackiej, która w zakresie wskazanego w tytule półwiecza jest obecna na kartach historii muzyki staropolskiej jedynie za sprawą związanego z przykościelną szkołą Jerzego Libana i zachowanych wzmianek o organach i organistach. Warto zatem postawić pytania o dźwiękową oprawę liturgii po zainstalowaniu tam wspaniałego Stwoszowego ołtarza, chodzi bowiem o świątynię wysokiej rangi: wyróżnioną przywilejami kościelnymi, objętą szczodrym patronatem patrycjatu i będącą miejscem ważnych uroczystości nie tylko religijnych, lecz także miejskich czy nawet państwowych³. Wypada też wspomnieć,
\end{abstract}

I Mirosław Perz, „W poszukiwaniu muzycznej paraleli krakowskiego przypadku Wita Stwosza”, w: Sztuka okoto I500. Materiaty Sesji Stowarzyszenia Historyków Sztuki, Gdańsk listopad I996, red. Teresa Hrankowska, Warszawa 1997, s. 315-323.

2 „Das Gesetz der Stellvertretung: Die Zeiten und die Völker, deren besonderes Kunstbedürfnis optisch gerichtet ist, treten im musikalischen Schaffen zurück. Das Gesetz kann umgekehrt werden”, zob.: Curt Sachs, „Die Musik in Rahmen der allgemeinen Kunstgeschichte”, Archiv für Musikwissenschaft 6 (1924) nr 3, s. 255-26I, cyt. s. 257.

3 Od XV w. proboszcz fary Mariackiej nosił tytuł archiprezbitera z przywilejem używania pontyfikaliów; odprawiano tu uroczyste nabożeństwa np. z okazji nominacji władz miejskich, wydarzeń historycznych (zwycięstwa wojenne, ważne fakty z życia panującej dynastii i in.). O uroczystościach związanych z elekcją rady 
że chodzi o dekady ważne w dziejach kościoła, znaczone m.in. fundacją sediliów dla rajców i ławników, kaplicy Kaufmana4, organów, kolegiów kapłańskich, a ze spraw organizacyjnych parafii - np. zmianami w układzie kazań polskich i niemieckich'.

Patronat krakowskiego mieszczaństwa nad farą Mariacką był w dużej mierze zinstytucjonalizowany, bowiem to senat (rada miejska) sprawował pieczę nad administracją i finansami kościoła oraz usytuowanej przy nim szkoły ${ }^{6}$, ponadto decydował o obsadzie stanowisk, w tym kantora i organisty (zob. il. I); do zadań mianowanych dożywotnio prowizorów (edylów) kościoła należał m.in. nadzór nad realizacją zamówień i remontów, w tym organów. Senat miał też prawo prezenty w przypadku niektórych kościelnych beneficjów (altarii, mansjonarii) 7 . Zatem wobec braku mariackich muzykaliów z tego okresu, to właśnie zachowane akta radzieckie pozwalają w dużej części na podejmowanie prób poznania muzycznych elementów liturgii tej świątyni i związanych z nią muzyków.

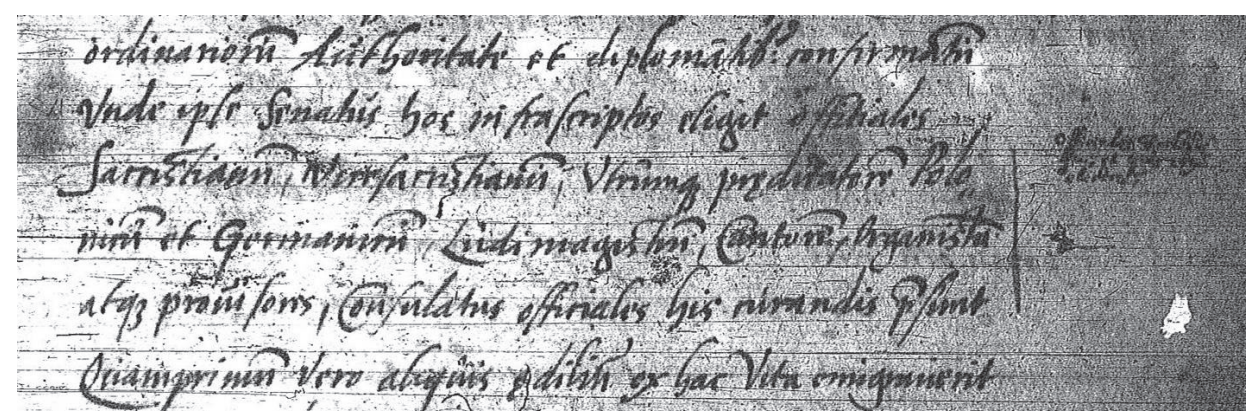

Il. I. Archiwum Narodowe w Krakowie (dalej ANK), Acta Eccl. et Monast. Crac., sygn. 3343, część Regestrum certorum censuum [...] p. 7: „Sam senat wybiera też wymienionych niżej oficjalistów: zakrystiana, wicezakrystiana, dwóch kaznodziejów: polskiego i niemieckiego, rektora szkoły, kantora, organistę, jak też prowizorów; oficjaliści owi podlegają radzie [...]”8. Reprodukcje w il. I-7 oraz 9-IO za zgodą Archiwum Narodowego w Krakowie (dalej ANK).

miejskiej zob.: Zdzisław Noga, Krakowska rada miejska w XVI wieku. Studium o elicie wtadzy, Kraków 2003, s. 23 i nast. Prawny patronat nad kościołem sprawował w tym czasie Zygmunt Stary, zob.: Elżbieta Piwowarczyk, „Mieszczańska «katedra». Patronat nad kościołem Mariackim w średniowieczu”, Nasza Przesztość 97 (2002), s. 6I.

4 Według najnowszych badań zachowane do dziśs stalle rajców i ławników powstały nie później niż w połowie XVI w., zob.: Waldemar Komorowski, Aldona Sudacka, Rynek Gtówny w Krakowie, Wrocław-WarszawaKraków 2008, s. 252-253; Krzysztof J. Czyżewski, „«Siądź mi po boku prawym». O zasiadaniu w kościele słów kilka”, w: Mecenat artystyczny a oblicze miasta. Materiaty LVI Ogólnopolskiej Sesji Naukowej Stowarzyszenia Historyków Sztuki. Kraków 8-Io XI 2007, red. Dariusz Nowacki, Kraków 2008, s. 60-6I, 63-7I. Zrekonstruowane niedawno oratorium Kaufmanów było jedną z renesansowych interpolacji w gotycką w stylu budowlę kościoła, zob.: Jerzy Żmudziński, „Kaplica Kaufmanów w wieży południowej kościoła Mariackiego w Krakowie (XVI-XVII w.). Na granicy przestrzeni publicznej i prywatnej miasta”, w: Mecenat artystyczny a oblicze miasta. Materiaty LVI Ogólnopolskiej Sesji Naukowej Stowarzyszenia Historyków Sztuki. Kraków 8-Io XI 2007, red. Dariusz Nowacki, Kraków 2008, s. 49.

5 E. Piwowarczyk, „Mieszczańska «katedra»”, op. cit., s. 58-59; Z. Noga, op. cit., s. 172-173.

6 Z. Noga, op. cit., s. 9, I4, 45, 6I-63.

7 Ibid., s. 224-225.

8 Polskie przekłady wykorzystanych tu tekstów łacińskich są autorstwa pani Ingi Grześczak, której składam w tym miejscu najserdeczniejsze podziękowanie. 
Wśród zapowiedzianych w tytule pytań przewija się kwestia „muzycznych miejsc” w Mariackiej świątyni. W jej rozległej przestrzeni wyodrębnione były - architektonicznie i funkcjonalnie - dwie strefy o różnym stopniu dostępności. Pierwsza z nich to strefa dla duchowieństwa, obejmująca prezbiterium z wielkim ołtarzem oraz znajdujący się przed nim chór, czyli przestrzeń z rzędami stalli, oddzielona od naw przegrodą chórową (lektorium) ${ }^{9}$. Po zachodniej stronie przegrody rozciągała się strefa dla wiernych; znajdowało się tu wówczas dwanaście kaplic, około trzydziestu ołtarzy ${ }^{\mathrm{IO}}$, w nawie głównej kazalnica (po prawej stronie przy drugim filarze od wejścia) i blisko ściany zachodniej - sedilia miejskiego senatu i ławników ${ }^{\mathrm{II}}$. Szczególną rangę miała kaplica usytuowana między wieżami nad kruchtą, spełniająca rolę oratorium elitarnej konfraterni Najświętszej Marii Panny ${ }^{\mathrm{I2}}$. Liturgia sprawowana w przestrzeni kościoła odpowiadała ustalonemu ceremoniałowi, w którym zarówno śpiew, jak i gra na organach spełniały określoną rolę, jednak wiadomości na ten temat są niepełne, rozproszone, niektóre wymagały weryfikacji. Przedstawiam je poniżej w kolejności od tematu mariackich organów i organistów, następnie zadań kolegium mansjonarzy, do muzyki w nabożeństwach wspomnianej konfraterni oraz roli kantora ${ }^{\mathrm{I} 3}$.

\section{ORGANY}

Sprawa budowy i konserwacji mariackich organów w omawianym półwieczu wydaje się dość dobrze rozpoznana. Była przedmiotem uwagi szerszego grona badaczy, bowiem organy, oprócz właściwej im roli muzycznej, spełniały też funkcję estetyczną jako element wnętrza świątyni ${ }^{\mathrm{I}}$; wiadomo, że w interesującym nas okresie zdobienie mariackich instrumentów powierzano znanym krakowskim artystom: w 1. I496 i I507-08 malarzowi Janowi Gorajowi, a pod koniec lat trzydziestych XVI w. malarzowi Tomaszowi Weissowi i snycerzowi Janowis. Podstawowe informacje

John Harper, Formy i uktad liturgii zachodniej od X do XVIII wieku, przekł. Małgorzata Kowalska, Kraków 2002, s. 52-53, 304, 321; K.J. Czyżewski, op. cit., s. 56-60. Po soborze trydenckim lektoria likwidowano, otwierając dla wiernych widok na ołtarz główny.

IO Kaplice i ołtarze były powiązane z fundacjami prywatnymi i korporacyjnymi. Przy niektórych z nich odprawiano nabożeństwa dla krakowskich cechów (kuśnierzy, szewców, krawców, piekarzy, rzeźników, karczmarzy, mydlarzy, łaziebników), zob.: Elżbieta Piwowarczyk, Dzieje kościota Mariackiego (XIII-XVI w.), Kraków 2000, s. 70.

II Ambona i sedilia pozostały na miejscu do dziś, zmieniała się natomiast tytulatura kaplic i ołtarzy.

I2 Kaplicę wybudowano na przełomie XIV i XV w., zob.: Józef Lepiarczyk, „Fazy budowy kościoła Mariackiego w Krakowie (wieki XIII-XV)", Rocznik Krakowski 34 (1959) nr 3, s. 209. Obecnie w jej miejscu jest muzyczny chór z organami.

I3 Niektóre z wykorzystanych tu źródeł nie były dotychczas prezentowane w literaturze muzykologicznej. Jeśli w przypisach podaję w pierwszej kolejności sygnaturę źródła, jest mi ono znane z autopsji; cytaty z tych źródeł podaję w pisowni oryginalnej, a cytaty z ekscerptów - w pisowni przyjętej przez autorów.

I4 Na ten temat zob.: Ewa Smulikowska, Prospekty organowe w dawnej Polsce, Wrocław 1989 (= Studia z historii sztuki 39); Marcin Zgliński, „Prospekty organowe - uwagi o metodologii, stanie i perspektywie badań”, w: $Z$ badań nad ikonografia muzyczną do I80o. Źródta - problemy - interpretacje, red. Paweł Gancarczyk, Warszawa 20I2, s. II5-I26. Wskazówki źródłowe w dalszych przypisach. 
źródłowe dotyczące tych zagadnień pochodzą z zespołów akt miejskich z Archiwum Narodowego w Krakowie (nazwa obecna). Najwcześniej sięgnął po nie Adolf Chybiński, publikując już ponad sto lat temu ekscerpty z ksiąg rachunkowych fary Mariackiej z 1. I495-I5IO oraz I539-45, opatrzonych wówczas tymczasowymi numerami 2150 i $5089^{16}$, które niebawem zmieniono na aktualne do dziś sygnatury 3342 i $3343^{17}$. Wypisy z innych dokumentów, pochodzących z 1. I489-90 oraz I495, I522 i I536, znajdują się w tomach Cracovia artificum ${ }^{\mathrm{I} 8}$ i w publikacjach ks. Bolesława Przybyszewskiego ${ }^{19}$, ich wybór zamieścił też w swej książce Jerzy Gołos ${ }^{20}$. Po ten cenny materiał źródłowy sięgali też z oczywistych względów historycy i historycy sztuki, z nowszych autorów wymienię tu Elżbietę Piwowarczyk ${ }^{21}$ i Aldonę Sudacką, której praca poświęcona organom w kościele Mariackim²2 zawiera jak dotąd najpełniejszą interpretację wpisów ze starszej księgi rachunkowej wykorzystanej przez Chybińskiego (należy wspomnieć, że sam Chybiński nie opatrzył swych ekscerptów szerszym komentarzem²3).

Warto podkreślić, że podjęcie budowy nowych organów ${ }^{24}$ zbiegło się w czasie $\mathrm{z}$ finalizowaniem pracy nad wspaniałym ołtarzowym retabulum (dla przypomnienia:

I6 Adolf Chybiński, „Z dziejów muzyki krakowskiej II. Przyczynek do historyi organistów i organmistrzów od XV do XVII wieku”, Kwartalnik Muzyczny 2 (I9I4) nr 2, s. 9I-IO8. Te nieaktualne sygnatury autor podawał jeszcze w swym Stowniku (Adolf Chybiński, Stownik muzyków dawnej Polski do roku I8oo, Kraków 1949); potem powtórzył je jeszcze Jerzy Gołos w książce Polskie organy i muzyka organowa (Warszawa 1972).

I7 Archiwum Narodowe w Krakowie: Acta Ecclesiarum et Monasteri Crac., sygn. 3342, 3343 (tę numerację wprowadzono już w I9I5 r., zob.: Katalog Archiwum Aktów Dawnych miasta Krakowa II. Rękopisy nr I-3568, Kraków 1915). W dalszym ciągu cytuję te źródła skrótowo jako ANK 3342 i ANK 3343, a ponieważ rachunki wpisywano od dwóch stron tomu, przed wskazaniem paginacji podaję tytuł odpowiedniej części (dla ANK 3342 Percepta lub Exposita, dla ANK 3343 Regestrum distributorum lub Regestrum certorum censuum).

I8 Cracovia artificum I300-I500, wyd. Jan Ptaśnik, t. 4, Źródta do historii sztuki i cywilizacji w Polsce, Kraków I9I7; Cracovia artificum I50I-I550, wyd. Jan Ptaśnik, Marian Friedberg, t. 5, Źródta do historii sztuki i cywilizacji w Polsce, zesz. I-3, Kraków 1936-48.

I9 Wypisy źródtowe do dziejów Wawelu. Z archiwów kapitulnych i kurialnych krakowskich I50I-I5, I5I6-26, I526-29, I526-35 (Artyści i rzemieślnicy krakowscy w latach I526-35), I530-33, I534-35, I536-38, I539-4I, I542-45, I545-I550), wybrał i opr. Bolesław Przybyszewski, Kraków 1965, 1970, 1984, 1985, 1986, 1987, I989, I991, I997, 2008 (= Źródła do dziejów Wawelu 4, 5, II/I,2,3,4, I2/I,2,3,4).

20 J. Gołos, op. cit., s. 246-250.

2I E. Piwowarczyk, Dzieje kościota, op. cit. (tu temat organów obszernie omówiony). Z prac historyków należy też wymienić artykuł Jerzego Rajmana „Organy, organmistrzowie i organiści w średniowiecznym Krakowie", w: Cracovia - Polonia - Europa. Studia z dziejów średniowiecza ofiarowane Jerzemu Wyrozumskiemu w sześćdziesiąta piątą rocznice urodzin i czterdziestolecie pracy naukowej, red. Waldermar Bukowski et al., Kraków I995, s. I47-I57.

22 Aldona Sudacka, „Zabytkowe organy w kościele Mariackim”, Rocznik Krakowski 60 (I994), s. 5I-74.

23 Wyjaśnił to następująco: „Przyczynek obecny jest jednym z najważniejszych dokumentów wpływów niemieckich w Polsce. Źródła, które wydaję, nie opatruję żadnym komentarzem”, zob.: A. Chybiński, „Z dziejów”, op. cit., s. 9I. Ta powściągliwa postawa badawcza może wydawać się dziś niezrozumiała, zwłaszcza że sporo odnotowanych w źródłowych wpisach nazwisk czy faktów ma polską konotację.

24 W literaturze podaje się, że najwcześniejsza wzmianka o organach w kościele Mariackim pochodzi z I399 r. (zob. np.: A. Sudacka, op. cit., s. 53), ale według Rajmana data jest niepewna i wymaga weryfikacji, zob.: Jerzy Rajman, „Unsere liebe Fraue. Wspólnota miasta i kościoła w Krakowie w XIV wieku”, Średniowiecze Polskie i Powszechne 4 (8) (20I2), s. I6I, przyp. 54. 
dzieło Wita powstawało w 1. I477-89). Zadanie to powierzono organmistrzowi Janowi Niedzieli, ale prace nie przebiegały pomyślnie z powodu nieporozumień między wykonawcą a reprezentującym fundatora - czyli radę miejską - Stanisławem Szworczem; skutkowało to pozwami sądowymi, zawieszeniem robót, powołaniem rewizorów i apelacją do wyższej instancji (dokładniej tę historię z 1. I489-90 przedstawia Bolesław Przybyszewski ${ }^{25}$ ). Prace nad instrumentem podjął w I495 r. sprowadzony z Frankonii organifex Petrus Handlar z Kitzingen, który zobowiązał się „opus novum organorum in ecclesia parochiali b. Virginis situm et locatum renovare, reformare, corrigere [...]"26 i zadanie to wykonał; jak wyżej wspomniano, artystyczne wykończenie prospektu powierzono malarzowi Gorajowi ${ }^{27}$. W kolejnych latach fachowej pomocy udzielał Stefan (Steffen, Steffanus) „de Kasimiria”28;

25 Krakowskie środowisko artystyczne czasów Wita Stwosza, wybrał i opr. Bolesław Przybyszewski, Wrocław-Warszawa-Kraków I990 (= Cracovia artificum. Supplementa 3), s. I88-I89; teksty źródłowe do tego zagadnienia zob.: Cracovia artificum I300-I500, op. cit., s. 3I4 (poz. IO3I), 3I6 (poz. I036), 317 (poz. I037), 320 (poz. I048, I049) oraz J. Gołos, op. cit., s. 246-247. Ponieważ u Jerzego Gołosa (ibid., s. 28I), Katarzyny Morawskiej (Średniowiecze część 2: 1320-I50o, Warszawa I998, s. 172), Aldony Sudackiej (op. cit., s. 54) oraz Piotra Matogi („Bazylika Archiprezbiterialna Wniebowzięcia NMP (Kościół Mariacki) - organy w nawie głównej”, strona www.organy.art.pl/ instrumenty.php?instr_id=979, dostęp I XII 20I7, opracowanie dla portalu Polskiego Wirtualnego Centrum Organowego) kwestia ta jest niedokładnie naświetlona, warto podać fakty przedstawione w dokumentach procesowych: sprawa toczyła się między organmistrzem Janem Niedzielą z jednej strony, a rajcą Stanisławem Szworczem ze strony drugiej; chodziło o dotrzymywanie warunków umowy (realizacji wypłat przez fundatora i respektowania terminów przez wykonawcę). Rozjemcą był wybrany przez obie strony inny rajca - Adam Szworcz, pełnomocnikiem Niedzieli - Jerzy z Wiślicy, pełnomocnikiem Stanisława Szworcza - Jan z Wieliczki. W celu uzyskania przez sąd opinii o pracy Jana, strony zostały zobligowane do powołania rewizorów biegłych w sztuce organowej. Pełnomocnik Szworcza prosił o wyznaczenie terminu oględzin i wezwał Tobiasza, Walentego od św. Ducha i Mikołaja (chodzi o ówczesnego organistę z kościoła Mariackiego) oraz Adama rajcę krakowskiego (ten fragment dokumentu jest dość zawiły i na jego podstawie Gołos pochopnie przyjął, że rajca Adam też był organmistrzem, por.: op. cit., s. 268). Jednak czynności zostały wstrzymane, bowiem pełnomocnik Niedzieli wniósł apelację z wnioskiem o skierowanie sprawy do wyższej instancji. Przybyszewski podaje, że nowe organy (które miały zastąpić instrument rozebrany w 1488 r.) nie zostały ukończone, a prace nad nimi podjęto dopiero w roku I495, zob.: Krakowskie środowisko, op. cit., s. I89. Trudności przy realizacji zamówień na organy nie były rzadkością, by przypomnieć np. sto lat późniejszą i bardziej dramatyczną historię budowy mariackich organów przez Hansa Humla, zob.: A. Chybiński, „Z dziejów”, op. cit., s. I05-IO6; A. Sudacka, op. cit., s. 52.

26 Tekst kontraktu w: Cracovia artificum I300-I500, op. cit., s. 373-375 (poz. I235); J. Gołos, op. cit., s. 248-249; świadkami podpisania dokumentu byli: wspomniany wyżej Stanisław Szworcz (wówczas prokonsul) oraz Joannes - organista kościoła Mariackiego. Warto tu wspomnieć, że z Kitzingen pochodził również działający nieco później Michael Lancz, twórca m.in. retabulum Nawrócenia św. Pawła we wspomnianej kaplicy fundacji Pawła Kaufmana (zob. przyp. 4).

27 ANK 3342 Exposita, p. 4; A. Chybiński, „Z dziejów”, op. cit., s. 92. Uwaga! Chybiński w ekscerptach z tych rachunków zastosował własną numerację ciągłą stron całej księgi, stąd wskazywana przez niego lokalizacja jest inna od podawanej tu przeze mnie paginacji widocznej w źródle (nb. wpisano tam tylko numery stron nieparzystych), zatem w odesłaniach do jego ekscerptów ograniczam się do podania odpowiednich stron tej publikacji.

28 ANK 3342 Exposita, p. 2I; A. Chybiński, „Z dziejów”, op. cit., s. 94. Chodzi o Stefana Rothoze z Przemyśla, który przyjął w I49I r. prawa miejskie podkrakowskiego Kazimierza, zob.: J. Gołos, op. cit., s. 247-248; Krakowskie środowisko, op. cit., s. I87. 
z treści dotyczących go wpisów z l. I497-I506 wynika, że naprawiał nie tylko organy określane jako duże („grosse orgel”), ale też drugi instrument („beyde werke yn der Kyrche") ${ }^{29}$.

W I506 r. rajcy zamówili kolejne nowe organy - wykonawcą zlecenia był Stanisław Zelik, utrwalony w rachunkach w różnych formach pisowni imienia i nazwiska (Stenczel, Stenczil, Stanislaus, Stanislaw; Selig, Szelig, Szelyg, Zelik, Zelyk), znany też pod nazwiskiem Warpęska ${ }^{30}$. Z zapisów wynika, że miał on wykonać nowe organy z pedałem i manuałem oraz pozytywem ${ }^{31}$ (zob. il. 2), wyszykować organy małe („anrichten dy cleyn orgel”) i w obu wprowadzić poprawki („von bessern das grosz werk und [...] beyde werk gebessert”) ${ }^{32}$; również te instrumenty zdobił Goraj, używając złota, srebra i lazurytu ${ }^{33}$. Z pierwszej połowy wieku zachowały się ponadto informacje o Andrzeju z Olkusza, który w I522 r., ku zadowoleniu prowizorów dobrze wykonał przebudowę któregoś z instrumentów, instalując nowe registry ${ }^{34}$, oraz o realizowanych od 1535 r. pracach nad nowymi organami - wiadomo o nich z senackiego dokumentu z I536 r., dotyczącego prolongaty terminu dla wykonawcy, czyli organmistrza Mikołaja ${ }^{35}$ (ciekawostką jest, że w pokryciu kosztów tej inwestycji miała być uwzględniona kara pieniężna nałożona na jednego z mieszczan krakowskich,

29 ANK 3342 Exposita, p. 5, 17, 2I, 22 (tu odnotowano „new regestrare”), 25 (ten wpis pochodzi z roku I508, ale dotyczy okresu wcześniejszego); A. Chybiński, „Z dziejów”, op. cit., s. 92, 93, 94, 99.

30 Dokładne informacje na temat postaci organmistrza i jego nazwisk (Zelik, Hermanzelig, Warpęska) podaje B. Przybyszewski, zob.: Wypisy źródtowe [...] I50I-I5I5, op. cit., s. Io (poz. I5), s. 80-8I (poz. 92), s. II4 (poz. I38). W ANK 3342 liczne wzmianki o Zeliku po kilka na stronach: Percepta, p. I2, Exposita, p. 23, 24, 25, 26; odnotowano tu też jego pomocnika Stanisława (ANK 3342 Exposita, p. 24); A. Chybiński, „Z dziejów”, op. cit., s. 92, 95-99, IOI.

3I Pozytyw wspomniany jest we wpisie dotyczącym kosztów złocenia obiektu („czu obyrgoldyn das positiw yn der ney orgel”) - ANK 3342 Exposita, p. 24; A. Chybiński, „Z dziejów”, op. cit., s. 97.

32 ANK 3342 Exposita, p. 23, 25; A. Chybiński, „Z dziejów”, op. cit., s. 95, 99. Niewykluczone, że użyta w notatce nazwa „cleyn orgel” dotyczy pozytywu. Na temat nazewnictwa zob.: J. Gołos, op. cit., s. 67.

33 ANK 3342 Exposita, p. 25, 26, 27; A. Chybiński, „Z dziejów”, op. cit., s. 98-Ior. Przyjmuje się, że zdobienie organów wykonał Jan Goraj, choć w źródle nazwisko występuje jedynie z określeniem „moler”. W jednej z późniejszych notatek wspomniany jest też „antonio moler” (ANK 3342 Exposita, p. 26; A. Chybiński, „Z dziejów”, op. cit., s. Ioo), a wiadomo, że imię Antoni nosił brat Jana, również uprawiający sztukę malarską (A. Sudacka, op. cit., s. 57). Przy budowie organów były też niezbędne prace snycerskie, ale w tym zakresie Zelik miał chyba własnego pomocnika: „Item off seyn schreybe des Stenczel Zeligs organiste dedi seynem dyner ader geselle Schnytczer 3 flor gleych vor michaeli" (I506); ANK 3342 Exposita, p. 24; A. Chybiński, „Z dziejów”, op. cit., s. 97.

34 „Generosus dominus Johannes Boner et Casper Beher provisores ecclesie B. Virginis in Circulo Crac. recognaverunt, quod ipsi [con]duxerunt cum Andrea de Ilkusch ad reformandum organum in ecclesia B. Virginis, quod ipse fecit sufficiens bonum cum regestris insolitis novis, plusque in construendo effecit quam cum dominis conduxerat. Quare prefati domini omne bonum de eo testificarunt (a. I522, f. 6, p. octavas Corporis Christi)"; podaję za: Cracovia artificum I50I-I550, op. cit., zesz. 3, s. 508-509, poz. 1277 .

35 Rajman identyfikuje tę postać z Mikołajem z Chrzanowa z katedry wawelskiej, co w świetle innych źródeł dotyczących tego organisty nie wydaje się przekonujące, zob.: J. Rajman, „Organy”, op. cit., s. I53. Bardziej prawdopodobne, że ten organmistrz jest tożsamy z Mikołajem zatrudnionym we wcześniejszej dekadzie do dokończenia prac przy instrumencie w katedrze gnieźnieńskiej (zob. dalej przyp. 57). 
zob. il. 3a, 3b); prawdopodobnie tego instrumentu dotyczą wzmianki o zdobieniu organów przez Jana Snyczera ${ }^{36}$ i Tomasza Weissa ${ }^{37}$. W kolejnym, ostatnim ze znanych dziś wpisów imiennych z tego okresu, odnotowano wypłatę dla organisty Bartłomieja za jego prace przy organach w roku $1543^{38}$; późniejsza informacja o wydatkach „pro reparandis organis in templo s. Mariae" pochodzi z I552 r. ${ }^{39}$.

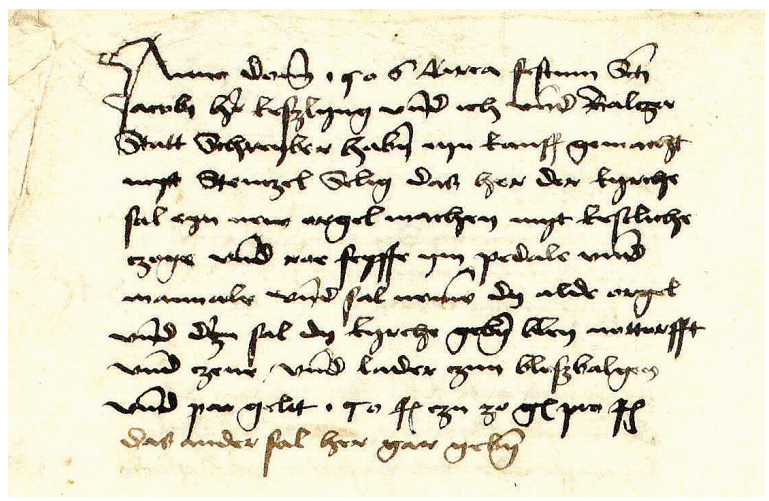

Il. 2. ANK Perc. et distr. Crac., sygn. 3342 część Exposita, p. 24: „Roku Pańskiego I506 około uroczystości św. Jakuba pan Reszlyng i ja oraz pisarz miejski Balcer zawarliśmy umowę ze Stenczilem Seligiem, by wykonał w kościele nowe organy z wybornymi cięgłami i [registrem] ror fayffe w pedale i manuale i wziął stare organy, a kościół winien do tego dać ołów, cynę i skórę na miechy i kwotę I50 florenów po 30 groszy [...]"40.

36 Ta forma pisowni nazwiska (odapelatywnego) przyjęta jest obecnie w literaturze, zob.: K.J. Czyżewski, op. cit., s. 7I, w źródle wpis „Joanne Schniczer” (ANK 3343 Regestrum distributorum, p. 3; A. Chybiński, „Z dziejów”, op. cit., s. I02). Wypłatę dla Snyczera odnotowano z datą 30 VII I539 r., ale według Przybyszewskiego prace snycerskie przy organach wykonał on dwa lata wcześniej (Wypisy źródtowe [...] I539-4I, op. cit., s. 134, przyp. I). Gołos, opierając się na ekscerptach Chybińskiego, zaliczył Snyczera do organmistrzów (op. cit., s. 287).

37 Wypisy źródtowe [...] I539-4I, op. cit., s. 69, przyp. I.

38 „Ad I Junij pono in distributis flor 40 quos Bartholomaeo organistae solui ad comissionem Spect. Senatus pro labore ipsius circa organum facto" (w dalszej notatce na tej stronie podano koszty naprawy stropu kościoła, powiązanej z pracami Bartłomieja), ANK 3343 Regestrum distributorum, p. I8; A. Chybiński, „Z dziejów”, op. cit., s. IO2; Cracovia artificum I50I-I550, op. cit., zesz. 3, s. 569-570, poz. I4I2. W tej części źródła znajduje się też kilka innych wpisów dotyczących prac przy organach, np. na wydatki w I539 r. „a labore circa consonantia organi” i na kalikanta (p. 3) czy w I54I r. na części do organów (p. 9, I3), podobnie w części Regestrum certorum censuum (I539 p. I5: „[...] pro colligendo Eleemosina ad nova organa [...]”, I540 p. 20, I543 p. 30). Podobnych wpisów może być więcej, ale stan zachowania niektórych kart źródła nie pozwala na ich dokładne odczytanie. Zob. też: A. Sudacka, op. cit., s. 57.

39 Chodzi o kwotę I2 florenów, przekazaną na ten cel organiście przez krakowskiego rajcę Bartłomieja Habichta, co odnotowano w rachunkach ANK Perc. et distr. Crac., sygn. I6I4 p. I55 i sygn. I6I5 p. II, podaję za: Cracovia artiticum I55I-I560, zesz. I, I55I-I552, wyd. Stanisława Panków i Zbigniew Wojas, WrocławWarszawa-Kraków I966, s. 238, poz. 653; zob. też Wypisy źródtowe [...] I545-I550, op. cit., s. I67, przypisy.

40 Wymieniony tu register występuje w innych źródłach z określeniem „Rohrpfeife” lub „Rohrflöte”; są to głosy z piszczałkami półkrytymi, zob.: Zenon Kobus, „Najstarsze nazewnictwo głosów organowych w Polsce”, Muzyka 28 (1983) nr 3, s. I05. Według tego autora, najstarszy przekaz tej nazwy w źródle polskim („,rorfayf”) pochodzi z kontraktu na budowę organów w Płocku z I508 r., ale krakowskie źródło jest dwa lata wcześniejsze. 


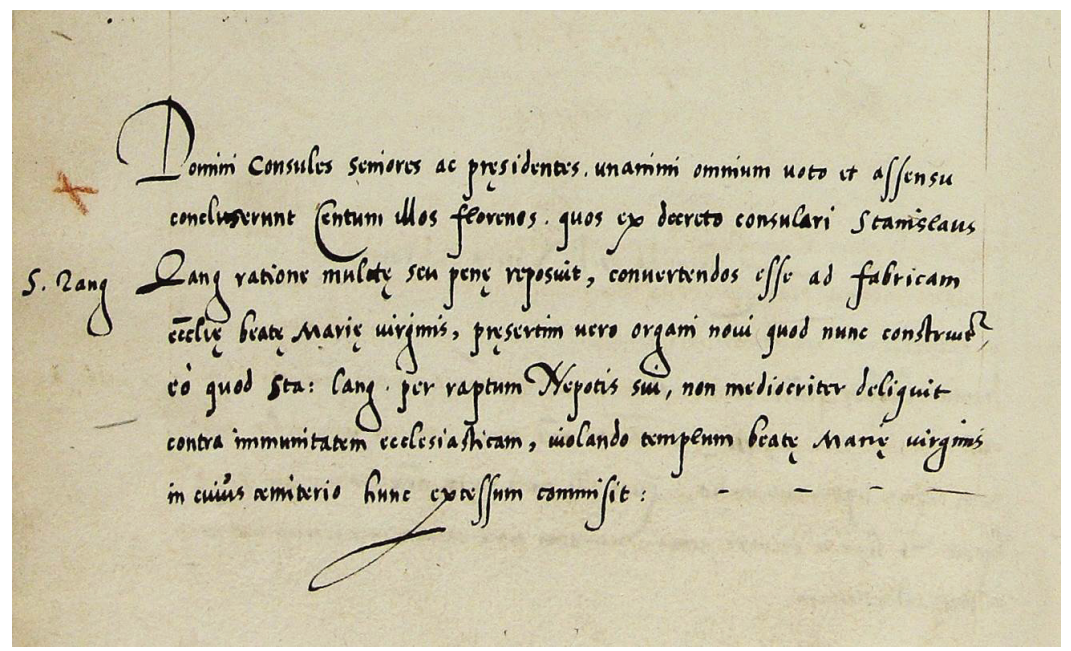

Il. 3a. ANK Consul. Crac., sygn. 435 p. 6o2: „Panowie rajcy i przełożeni jednogłośnie postanowili, że owych sto florenów, które na mocy uchwały rajców Stanisław Lang złożył jako karę czy też pokutę, należy przeznaczyć na prace w kościele Najświętszej Marii Panny, zwłaszcza zaś na nowe organy, które są właśnie w budowie. Bowiem rzeczony pan Lang przez zerwanie swego zobowiązania w znacznym stopniu naruszył przywilej kościelny, znieważając świątynię Marii Panny na kościelnym cmentarzu, gdzie dopuścił się tego wykroczenia” [I535, poniedziałek po święcie Nawiedzenia NMP].

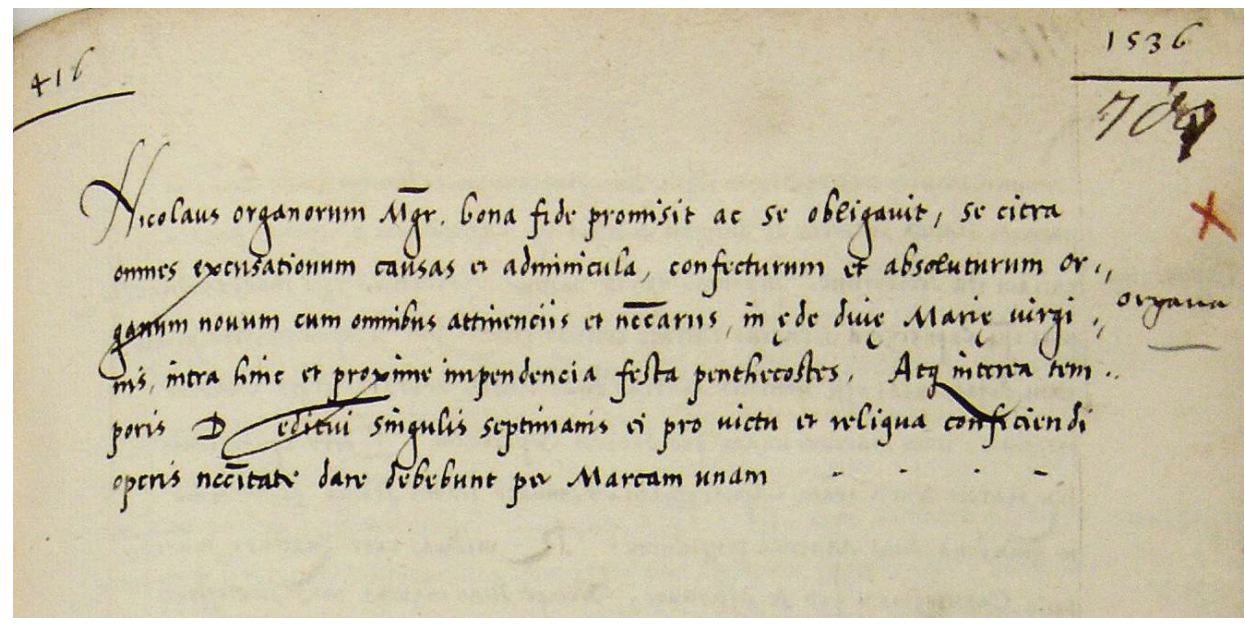

Il. 3b. ANK Consul. Crac., sygn. 435 p. 709: „Organmistrz Mikołaj w dobrej wierze przyrzekł i zobowiązał się, że, mimo wszelkich powodów do wymówek co do wsparcia, wykona i zakończy prace nad nowymi organami i całym ich niezbędnym wyposażeniem w kościele Najświętszej Marii Panny w terminie od tego dnia do najbliższych Zielonych Świąt. Pieniądze powinny być mu wypłacone według zlecenia w poszczególnych tygodniach w wysokości jednej marki na wikt i pozostałe niezbędne do pracy potrzeby" [1536, piątek, nazajutrz po dniu Nawrócenia św. Pawła]. 
Z przedstawionych informacji można wnosić, że w omawianym okresie powstały w farze Mariackiej trzy dzieła organmistrzowskie: I) pod koniec XV w. - Jana Niedzieli kontynuowane przez Piotra Handlara, 2) w pierwszej dekadzie XVI w. - Stanisława Zelika/Warpęski, 3) w trzeciej dekadzie - Mikołaja. W treści wpisów (zwłaszcza odnoszących się do prac Zelika) jest sporo cennych dla organologów wzmianek dotyczących spraw szczegółowych ${ }^{41}$, ale w kwestii pytań o lokalizację, kształt, a nawet o liczbę instrumentów nie dają one badaczom wyczerpujących odpowiedzi ${ }^{42}$. Należy przyjąć, że zgodnie z praktyką epoki, jak też wspomnianym tu na wstępie rozplanowaniem przestrzeni świątyni, jeden instrument usytuowany był w pobliżu wielkiego ołtarza $^{43}$. Przybyszewski przyjmuje, że w tym miejscu, blisko dzieła Stwosza, znajdowały się organy Niedzieli/Handlara ${ }^{44}$, co wydaje się przekonujące. Nie wiadomo jednak, i pozostanie to w sferze pytań, czy organy te były ustawione na poziomie posadzki, czy na poziomie wyższym (podobnie, jak na znanym sztychu z widokiem instrumentu późniejszego o ponad sto lat45).

W przypadku pytania o lokalizację dzieła Zelika można brać pod uwagę dwie możliwości. Aldona Sudacka przypuszcza, że był to instrument określany we wzmiankach z początku następnego stulecia jako organy „nad kazalnicą” lub „krzywe” ${ }^{6}$. Trzeba jednak pamiętać, że choć zamówiono u niego organy nowe, to polecono wykorzystać obiekt dawniejszy („sal nemen dy alde orgel” 47 - zob. il. 2) i chyba nie chodziło tu o organy wykończone przez Handlara dziesięć lat wcześniej. Wiadomo, że przed podjęciem prac przez Zelika były w farze dwa instrumenty; wynika to z zadań zleconych

Dotyczą głównie wypłat (dla organmistrza, malarza, rzemieślników) i zakupu materiałów (cyna, ołów, złoto, srebro, lazuryt, drewno na klawisze, skóra na miechy, drut i in.).

42 Wynika z nich np., że u progu XVI w. były w kościele organy „stare” $i$,nowe”, a jedne z nich były „duże”, zob. przyp. 32.

43 Arnolt Schlick w swoim Spiegel der Orgelmacher und Organisten z I III r. podkreślał znaczenie trafnego wyboru miejsca organów, bowiem z uwagi na ich udział w liturgii pożądana jest dobra słyszalność, zob.: Piotr Towarek, „Arnolta Schlicka traktat Spiegel der Orgelmacher und Organisten z I5II roku”, Studia Elblaskie 6 (2004/2005), s. 2II. Zachowane źródła ikonograficzne z tego czasu potwierdzają umieszczanie instrumentów w pobliżu prezbiterium, zapewniające dobry kontakt organisty ze śpiewakami uczestniczącymi w nabożeństwie, zob.: Robert Haas, Aufführungspraxis der Musik, Potsdam 193I, s. 137 (reprodukcja drzeworytu Hansa Weiditza przedstawiającego śpiewaków Heinricha Isaaca i towarzyszącego im na organach Paula Hofhaimera w obecności uczestniczącego w nabożeństwie cesarza Maksymiliana I) oraz Walter Salmen, Musikleben im I6. Jahrhundert, Leipzig 1976 (= Musikgeschichte in Bildern 3: Musik des Mittelalters und der Renaissance 9), s. I80-18I (tu inny drzeworyt Hansa Weiditza z podobną sceną: w pobliżu ołtarza Hofhaimer przy organach, obok śpiewacy pod kierunkiem succentora).

44 Krakowskie środowisko, op. cit., s. I89.

45 Frontyspis druku Synodus dyoecesana [...] celebrata Anno Domini MDCXLIII, Kraków, Andrzej Piotrkowczyk [1643?], zob.: Jerzy Gołos, „Najstarsze polskie źródła ikonograficzne do historii organów”, Ruch Muzyczny 29 (1985) nr I6, s. 23-24.

46 A. Sudacka, op. cit., s. 56; P. Matoga, op. cit. (zob. przyp. 25).

47 ANK 3342 Exposita, p. 24. Jerzy Mizgalski interpretował ten wpis inaczej, według niego stare organy miały być częścią wynagrodzenia dla Zelika, zob.: J. Mizgalski, „Organiści i organmistrze polscy jako źródło rozprzestrzeniania się muzyki profesjonalnej na terenie Polski do końca XVIII wieku", w: Prace naukowe Instytutu Muzykologii UW, t. I, Warszawa 1961, s. 78. 
wspomnianemu wyżej Stefanowi, a potwierdza jedna z notatek dotyczących zabezpieczenia sklepień nad organami (I5OI: „Das gebewde der apsewte der Kirche obyr den 2 orgil" ${ }^{8}$ ). Ów drugi instrument mógł znajdować w przeciwległej do głównego ołtarza części kościoła, mianowicie we wspomnianej kaplicy ulokowanej między wieżami, a przynależnej do patrycjuszowskiej konfraterni Wniebowzięcia Najświętszej Marii Panny (wiadomo, że bractwo miało zapisane w statutach wynagrodzenie dla organisty uczestniczącego w odprawianych tam nabożeństwach $\left.{ }^{49}\right)$. Istnienie organów „na chórze zachodnim” przyjmuje też - zgadzając się z Chybińskim - Sudacka, opatrując to uwagą, że prospekt tego instrumentu mógł dobrze zamykać przestrzeń kaplicy od strony nawy głównej ${ }^{50}$. Nie jest zatem wykluczone, że organy Zelika miały zastąpić dawniejszy obiekt w brackim oratorium; takie domniemanie mogłaby potwierdzać źródłowa notatka o przekazaniu organiście kluczy do wieży, skąd mogło być dojście do instrumentu („Item Georgio organista vor 2 slossel czu dem Turme unnd orgel"sI). Z innej wzmianki o kluczach wynika, że organy Zelika znajdowały się nad kamiennymi schodami („Item geben vor slosz unnd 2 gute szlossel [...] czu der orgel off der Steynen treppe peractum anno domini $1507{ }^{\text {" } 52}$ ), ale tu wypada przyznać, że w równej mierze mogło to dotyczyć miejsca nad kazalnicą. Lokalizacja kolejnych określonych jako „nowe” organów, konstruowanych w połowie lat trzydziestych przez Mikołaja, pozostaje jak dotąd w sferze domysłów - nie wiadomo, czy był to trzeci instrument w świątyni, umiejscowiony właśnie nad kazalnicą, czy miał zająć miejsce obiektu istniejącego wcześniej. Nie można też wykluczyć, że był tu również w użyciu instrument przenośny (portatyw, który bywał też określany jako pozytyw).

Na pytanie o kształt tych dzieł źródła dają częściową odpowiedź tylko w przypadku organów Zelika i Mikołaja, a co do instrumentu Niedzieli/Handlara można jedynie zakładać, że pod względem konstrukcji i wyglądu nie odbiegał od norm czasu i miejsca, zatem mógł przypominać obiekty opisane w traktatach czy odwzorowane w grafice ${ }^{53}$. Z rachunkowych notatek dotyczących prac Zelika i Goraja wiadomo, że ich organy były utrzymane w tonacji kolorystycznej złoto-srebrno-lazurowej oraz miały prospekt zamykany ruchomymi skrzydłami i zwieńczony kunsztownym szczytem 54 , natomiast konstrukcji mechanizmu dotyczą tylko ogólne

48 ANK 3342 Exposita, p. I5; podobnej sprawy dotyczy notatka z I5O2 r.: ,von bessern dy apseyte obyr der grosz orgil”, ibid., p. I4.

49 Zob. dalej przyp. 70 i 162.

50 A. Sudacka, op. cit., s. 54.

5I ANK 3342 Exposita, p. 27; A. Chybiński, „Z dziejów”, op. cit., s. Ioo.

52 ANK 3342 Exposita, p. 26; A. Chybiński, „Z dziejów”, op. cit., s. Ioo.

53 Np. w traktacie Arnolta Schlicka, czy w grafikach Hansa Weiditza (zob. przyp. 43) lub Hansa Burgkmaira. Zob. też: Curt Sachs, Historia instrumentów muzycznych, przekł. Stanisław Olędzki, Kraków I989, s. 28I-285.

54 Mógł w swym kształcie odpowiadać jednemu z typów prospektów z końca XV i I poł. XVI w., prezentowanych w publikacji Smulikowskiej (op. cit., tab. po s. 2I6, poz. 3-7). 
wzmianki o miechach, wentylach czy registrach 55 . Wykonany po około trzydziestu latach instrument Mikołaja również miał skrzydłowe zamknięcie, zdobione przez malarza Tomasza ${ }^{56}$. Warto tu napomknąć, że Zelik, podczas realizacji zamówienia w kościele Mariackim, pracował równolegle nad organami w wawelskiej katedrze ${ }^{57}$, zatem nie można wykluczyć jakichś podobieństw między tymi obiektami ${ }^{58}$. Być może organy mariackie były podobne do instrumentu katedralnego, o którym mamy pewne wyobrażenie dzięki ich użytkownikowi - Mikołajowi z Chrzanowa, bowiem w 1547 r. sporządził on rejestr poprawek, jakie winien wykonać organmistrz; z notatki tej wynika, że wawelskie organy obejmowały „wielkie opus” i pozytyw, były z pedałem i miały dwadzieścia pięć registrów, z których wymienione są z nazwy: pryncypał, mikstura, puzon wielki i mały, trąba, szałamaja i cymbał 59 . Warto pamiętać, że był to czas przemian - od zalecanej przez Schlicka w I5II r. dobrej dyspozycji obejmującej osiem lub dziewięć registrów ${ }^{60}$, do ponad dwudziestu registrów w kolejnych dekadach półwiecza (nie bez powodu mariaccy prowizorzy byli radzi z efektów pracy Andrzeja z Olkusza ${ }^{61}$ ).

\section{ORGANIŚCI}

Źródła nie zawsze dają podstawę do precyzyjnego rozgraniczenia profesji organisty od organmistrza, bowiem miano „organista” było używane nie tylko w węższym znaczeniu na określenie muzyka-wykonawcy, ale i ogólnym, wskazującym

55 W I508 r. odnotowano wydatek na „7 czymmel czu der orgel” (ANK 3342 Exposita, p. 25; A. Chybiński, „Z dziejów”, op. cit., s. 98) - być może chodzi o dzwonki tworzące tzw. Cymbelstern (snycerska gwiazda z wirującymi dzwonkami, zob. J. Gołos, op. cit., s. 264; Z. Kobus, op. cit., s. Io6).

56 "Thomae pictori [...] a pictura alarum organi novi [...] fl. IO”, podaję za: Cracovia artificum I50I-I55O, op. cit., zesz. 3, s. 553 , poz. 1372.

57 Prawdopodobnie przejął budowę po Stanisławie Komorowskim (zob.: Adolf Chybiński, „Mikołaj z Chrzanowa. Przyczynek do historii muzyki krakowskiej w XVI wieku", Przeglad Muzyczny I (1925) nr 20, s. 2) i zakończył w 1508 roku. Efekt tej pracy kapituła oceniła bardzo wysoko (Wypisy źródtowe [...] I505-ISIS, op. cit., s. 80-8I, poz. 92). Należy dodać, że oba zlecenia krakowskie podjął po opuszczeniu rozpoczętej w pierwszych latach XVI w. budowy organów w Gnieźnie, za co tamtejsza kapituła wytoczyła mu później sprawę o zerwanie umowy. Instrument ten dokończył dopiero w 1. 1519-22 organmistrz Mikołaj, zob.: Wypisy źródtowe [...] ISOI-ISIS, op. cit., s. IO (przypis), II4, poz. I38; Ireneusz Pawlak, „Organy i organiści katedry gnieźnieńskiej do połowy XVI wieku”, Summarium: Sprawozdania Towarzystwa Naukowego KUL 5 (25) (1978) za rok 1976, s. 72-75. Zatem również Zelik wpisuje się w temat wspomnianych wyżej kłopotów z dotrzymywaniem zobowiązań organmistrzowskich (zob. przyp. 25).

58 Według Gołosa odwzorowanie organów katedralnych z ok. I5ı r. widnieje na powszechnie znanej miniaturze z pontyfikału Erazma Ciołka, przedstawiającej koronację króla: na północnej ścianie przy prezbiterium katedry ulokowany był pozytyw, a na przeciwległej - duży prospekt zamykany dwuskrzydłowymi drzwiami, zob.: J. Gołos, „Najstarsze polskie źródła”, op. cit., s. 23-24. W świetle źródeł problem wygląda nieco inaczej, zob. mój komunikat „Mikołaj z Chrzanowa - addenda” w niniejszym zeszycie Muzyki (s. IOI-IO7).

59 A. Chybiński, „Mikołaj z Chrzanowa”, op. cit., nr 2I, s. I; J. Rajman, „Organy”, op. cit., s. 175-176;

E. Zwolińska, „Mikołaj z Chrzanowa”, op. cit., s. Io7.

60 C. Sachs, op. cit., s. 283.

6I Zob. przyp. 34. 
na związek danej postaci z instrumentem. Badacze zwykle opatrują ten problem komentarzem, że każdy organista znał się na budowie organów, a niektórzy budowniczowie tych instrumentów spełniali też rolę praktykujących muzyków ${ }^{62}$. Jednak wymienione uprzednio postaci, zaangażowane w budowę instrumentów mariackich, określane są na ogół precyzyjnie jako: „magister organorum” (Niedziela), „organifex” (Handlar), „orgelmeister” (Zelik, nb. określony też kilkakrotnie jako „organista”), „organorum Mgr” (Nicolaus), a to jednoznacznie wskazuje na ich specjalność organmistrzowską; inne osoby, związane z naprawą czy modernizacją instrumentów, figurują w rachunkach jako „organista und bleydecker” (Stefan), „organista” (Bartłomiej) lub w ogóle bez określenia zawodu (Andrzej z Olkusza). Do organmistrzów zalicza się też w niektórych publikacjach dwóch mariackich organistów z tego półwiecza - Jorga Schwarcza i Maksyma Dubrawskiego, ale ta kwalifikacja nie znajduje uzasadnienia w źródłach ${ }^{63}$. Natomiast przykładem łączenia funkcji organisty i organmistrza może być Marcin, związany z farą w 1. I549-56 (a może i wcześniej, I540-45), który jest najpewniej tożsamy z Marcinem z Jędrzejowa (Andreopolita), powołanym w I552 r. na dwór królewski, a trzy lata później zobligowanym przez monarchę do włączenia się w prace przy budowie organów wielickich, zaniedbywanej przez organmistrza Józefa ${ }^{64}$.

Podstawą dla ustalenia imion organistów uczestniczących w liturgii mariackiej $\mathrm{w}$ interesującym nas czasie mogą być regularne wypłaty wynagrodzenia dokonywane zwykle kwartalnie i takie pozycje znajdujemy w przytaczanych tu rachunkach edylów (ANK 3342 i ANK 3343), a około połowy wieku również w rachunkach krakowskiej pretorii (ANK Perc. et distr. Crac., sygn. I6I3-I8). W spisywanych naj-

62 O stosunkach między przedstawicielami tych profesji pisał m.in. Arnolt Schlick, ostrzegającich, by dla zysku nie stawali się „dwojgiem w jednym” i zachęcając do roztropnej współpracy, wolnej od zazdrości o sukces, zob.: P. Towarek, op. cit., s. 2Io. Schlick zalecał też umiar w nakładach, podając przykładowo dużą rozpiętość kosztów nowych instrumentów: 400, 500, 600, 1000 a nawet 2000 guldenów (ibid.); dokumenty krakowskie pozwalają odnieść się do jednej z tych wielkości, mianowicie do gwarantowanej sumą Iooo florenów umowy z Handlarem - zob. przyp. 26 (gulden miał wartość porównywalną z florenem); rachunki dotyczące budowy innych instrumentów mariackich nie pozwalają na precyzyjne określenie całości kosztów.

63 Do organmistrzów zaliczył Schwarcza Jerzy Gołos (op. cit., s. 285, 319), powołując się przy tym na ekscerpty Chybińskiego, wskazał jednak fragmenty, w których odnotowane są tylko wypłaty kwartalne dla Jorga jako organisty; w dalszych fragmentach źródła są wpisy, w których odnotowano przekazywanie pieniędzy przez Jorga Zelikowi („per Georgium [...] dem Zelig”), co tylko potwierdza oczywisty kontakt muzyka z konstruktorem organów (ANK 3342 Exposita, nlb wklejka między p. 24 a 25, trzy wpisy z I508 r.: „Item die sancti Laurenti [...] dedi per Georgium organista 2 fl. dem Zelig”, „Item in vigilia nativitatis marie dedi per Georgium organistam 3 flor. dem Zelig”, „Item Schabato post exaltationis Sancte Crucis festum dedi per Georgium organistam flor. 2 et hos florenos debet inscribere Zelig in suum registrum", zob.: A. Chybiński, „Z dziejów”, op. cit., s. 97, 98. Natomiast Dubrawskiego jako organmistrza wymieniono w następujących publikacjach: A. Chybiński, Stownik muzyków, op. cit., s. 24; hasło „Organiści”, w: Stownik muzyków polskich, red. Józef Chomiński, t. 2, Kraków 1967, s. 93; J. Gołos, op. cit., s. 40, 271, 319.

64 Elżbieta Zwolińska, „O Marcinie Andreopolicie - organmistrzu i muzyku w służbie Zygmunta Augusta”, w: Muzykolog wobec świadectw źródtowych i dokumentów. Ksiegga pamiątkowa ofiarowana Profesorowi Piotrowi Poźniakowi w 70. rocznice urodzin, red. Zofia Fabiańska et al., Kraków 2009, s. I23-I46. Zob. też: Cracovia artificum IS5I-IS60, zesz. I, ISSI-IS52, op. cit. (zob. przyp. 39), s. 245, przyp. do poz. 672. 
pewniej przez prowizora Adama Schwarcza ${ }^{65}$ wydatkach z 1. I495-I5IO są wskazani czterej organiści:

I495-I500 - Johannes ${ }^{66}$, identyfikowany przez Przybyszewskiego ze zmarłym w I5O3 r. Janem z Łużyc („Joannes de Lusacia”) ${ }^{67}$; otrzymywał wynagrodzenie w wysokości ośmiu florenów rocznie (wypłacane po dwa floreny kwartalnie), był też beneficjentem altarii Zwiastowania Najświętszej Marii Panny ${ }^{68}$; prawdopodobnie miał ucznia $^{69}$; czynny był podczas prac organmistrzowskich Handlara; poprzednikiem Johannesa był organista Nicolaus ${ }^{70}$.

I499-I5IO - Jorg Stenczil Schwarcz (Jorge, Georgius, Georg) ${ }^{71}$; „Stenczil” to patronimium - był synem wspomnianego tu wcześniej rajcy Stanisława Schwarcza; początkowo pobierał takie wynagrodzenie, jak poprzednik, ale w I505 r. kwota wzrosła do dwunastu florenów rocznie (wypłaty po trzy floreny kwartalnie); Jorg był świadkiem powstawania organów Stanisława Zelika; organistą u fary mógł być też po I5Io r., ale brak źródeł dotyczących jego późniejszej działalności.

I502-03 - Petter (Petrus) z pensją dwóch florenów za kwartał ${ }^{72}$.

I508-09 - Szczęsny (Sczeysny, Sczeszny, Sczeynszny) z pensją trzech florenów kwartalnie ${ }^{73}$.

Jak widać, w niektórych latach tego okresu było w farze równocześnie dwóch organistów (Johannes i Jorg, Jorg i Petter oraz później Jorg i Szczęsny).

Kolejna zachowana księga rachunkowa fary, prowadzona prawdopodobnie przez prowizora Justusa Ludwika Decjusza ${ }^{74}$, pochodzi dopiero z 1. I539-45, zatem w do-

65 Można to wnosić na podstawie notatki na okładce ANK 3342 od strony Percepta („Regestrum Eclsie Beatisiime Vrg Marie quod dominus Adam Schwarcz olim provisor conscripsit et post mortem suam [...] reliquit $[\ldots] ")$.

66 ANK 3342, kilkanaście wpisów w części Exposita, p. 4, 6, w Percepta jeden - p. 7; A. Chybiński, „Z dziejów”, op. cit., s. 9I-9I.

67 Krakowskie środowisko, op. cit., s. I84.

68 Ibid.

69 ANK 3342 Exposita, p. 4, I498: „dedi dem Junge Johannes organiste 2 fl sein lon”; A. Chybiński, „Z dziejów”, op. cit., s. 92.

70 Mikołaj był zatrudniony w I473 r., w I480 r. toczył spór o wynagrodzenie z wymienianym już tu wcześniej Stanisławem Schwarczem; jako organista fary działał co najmniej do I490 roku. Podaję za Przybyszewskim, zob.: Krakowskie środowisko, op. cit., s. I83. „Nicolaus organista” jest na liście członków bractwa Wniebowzięcia NMP z I48I r. - rkp. sygn. 2365 Biblioteki Jagiellońskiej w Krakowie (dalej BJ 2365), f. IIr.

7I ANK 3342, w Exposita ponad dwadzieścia wpisów na p. 6, I5, 2I, 22, 23, 25, 27, 2, w Percepta jeden - p. I6; A. Chybiński, „Z dziejów”, op. cit., s. 92-Ior. Prawdopodobnie Jorg był związany z farą dłużej, ale brak źródeł po I 5 IO roku.

72 ANK 3342 Exposita, p. I7; wpisane są tu trzy wypłaty kwartalne: za kwartał św. Krzyża I5O2 (kwartały oznaczano nazwami przypadających w nich świąt) z zaznaczeniem, że to pierwsza wypłata („[...] dedi dem Petter organista [...] den yrste lon”), za kwartał św. Łucji i następnie za kwartał Środy Popielcowej, już pewnie następnego roku, zob.: A. Chybiński, „Z dziejów”, op. cit., s. 93-94.

73 ANK 3342 Exposita, p. 25, 27; wpisano tu cztery wypłaty za kwartały: św. Krzyża i św. Łucji I508 r. oraz Środy Popielcowej i Zielonych Świąt I509 r. (w tym ostatnim otrzymał tylko $2^{1 / 2}$ florena); A. Chybiński, „Z dziejów”, op. cit., s. 93-94.

74 Tak przypuszcza Marian Friedberg, zob.: Cracovia artificum I50I-I550, op. cit., s. 553. 
stępnej dziś dokumentacji jest niemal trzydziestoletnia luka. W literaturze pojawia się wprawdzie informacja, że w l. I509-I2 grał u fary Stanisław Zelik/Warpęska (czego nie można wykluczyćc75), a według Chybińskiego w 1. 1515-45 działał tu organista Marcin $^{76}$; ta druga informacja jest jednak wątpliwa, bowiem jako jej podstawę Chybiński podał źródło ANK 3343, które dotyczy tylko 1. I539-45, kiedy taki organista rzeczywiście się pojawia, ale z zapisów wynika, że pracę rozpoczął dopiero w I540 roku. Przedstawmy zatem organistów wymienionych w rejestrze ANK 3343; są to cztery (lub pięć) postaci:

I539 - Stanisław (Stanislaus organista) 77 , z jego rąk na początku tego roku otrzymał klucze wymieniony niżej organista Maksym Dubrawski (zob. il. 4). Trudno ustalić, od kiedy i jak długo Stanisław był zatrudniony w farze i na jakich warunkach. Prawdopodobnie jest tożsamy z wymienionym w zapisie z akt kurialnych z I530 r. Stanisławem z Pokrzywnicy, organistą „ad Sanctam Mariam in circulo Cracoviensi”, i potem, we wpisach z l. I543 i I550 już tylko z samym imieniem jako organista tego kościoła $^{78}$.

I539-40 - Maksym Dubrawski (Maxim, Maximus, Dubrawszki, Dobrawer). W warunkach służby tego muzyka zwraca uwagę wysokie wynagrodzenie i zastrzeżenie, by nie nakładano nań dodatkowych obowiązków (zob. il. 4). Uposażenie zostało mu jeszcze podwyższone w trzecim kwartale I539 r., najwyraźniej w uznaniu muzycznych umiejętności, co wynika z notatki edyla, której obszerny fragment w przekładzie polskim podaję poniżej:

Należy zaznaczyć, że od tego kwartału [zawarty] został nowy kontrakt z Maksymem organistą, tak że za poszczególne kwartały powinno mu się kolejno dawać ıз fl., aby

75 Stownik muzyków polskich, op. cit., t. 2, s. 93; J. Rajman, „Organy, organmistrzowie”, op. cit., s. I53. O aktywności Zelika/Warpęski jako organisty wnioskuje się m.in. na podstawie dokumentu, w którym kapituła udziela zezwolenia Mikołajowi z Chrzanowa na opuszczenie Krakowa w czasie zarazy w I527 r. pod warunkiem przekazania kluczy do instrumentu „substituto aut domino Stanislao Varpąska”, zob. Wypisy źródtowe [...] I526-I529, op. cit., s. 64, poz. I29.

76 ANK 3343. Chybiński, Stownik muzyków, op. cit., s. 79 (tu wskazana dawna sygnatura 5089); informacja powtórzona w Stowniku muzyków polskich, op. cit., t. 2, s. 93. Gołos (op. cit., s. 280) też podaje takie ramy czasowe, tyle że dla Marcina organmistrza, który miałby wtedy pracować przy organach mariackich. Należy tu wspomnieć, że w krakowskich aktach sądowych z I535 r. pojawia się bliżej nieokreślony „Martinus organista” jako uczestnik sporu z Franciszkiem z Szydłowa - katedralnym kantorem „cori et scholarum" (Wypisy źródtowe [...] I534-I535, op. cit., s. I3, poz. I309). W tym kontekście Jan Krukowski uznał Marcina za organistę katedralnego, ale to przyporządkowanie nie znajduje potwierdzenia w innych źródłach, zob.: Jan Krukowski, Nauczyciele szkót parafialnych Krakowa w XVI wieku, Kraków 2007, s. 55.

77 ANK 3343 Regestrum certorum censuum, p. I4 (Uwaga! dla tej części księgi Chybiński podaje w swych ekscerptach - niekiedy mylną - foliację, w niniejszej pracy wskazuję paginację według ołówkowego zapisu w źródle.)

78 Wypisy źródtowe [...] I530-I533, op. cit., s. I5, poz. 402; Wypisy źródtowe [...] I542-I545, op. cit, s. IO5, poz. 1327; Wypisy źródtowe [...] I545-I550, op. cit., s. 307, poz. 2579. Warto wspomnieć, że w I522 r. krakowskie prawo miejskie przyjął „Stanislaus Malek [Malck?] organista de Sandomiria”, o którego działalności jak dotychczas nic nie wiadomo. Podaję za: Cracovia artificum I50I-I550, op. cit, zesz. 3, s. 509, poz. I279; zob. też: A. Chybiński, Stownik muzyków, op. cit., s. 78 (na s. II8 Stownika autor wskazuje też Stanisława organistę czynnego w Krakowie ok. I530 r.). 
miał rocznie $52 \mathrm{fl}$. Lecz oprócz jednego florena tygodniowo pozostaje 20 fl. do wypłacenia w pierwszej kolejności przez prowizorów Kościoła NMP, jak i wedle dawnego zwyczaju $8 \mathrm{fl}$. od bractwa oraz $2 \mathrm{fl}$. wyliczone przez pana Plebana tytułem dodatku, zatem w sumie $22 \mathrm{fl}$., które winny być wypłacane przez pretorię [...] z tytułu prawomocnego zatwierdzenia przez miasto. Panowie rajcy postanowili przydać mu tę zapłatę [imiennie], aby - na wypadek jego odejścia - inny organista daleko gorszy od niego w tej umiejętności nie zechciał uznać tej opłaty jako zwyczajowo należnej. Do tego panowie lonerzy ${ }^{79}$ winni mu pokrywać koszt mieszkania i jedenastu miar drewna na opał. To postanowienie podjęli panowie rajcy w pełnym składzie [...] On sam zaś przez dwa najbliższe lata nie może odejść ze służby ${ }^{80}$.

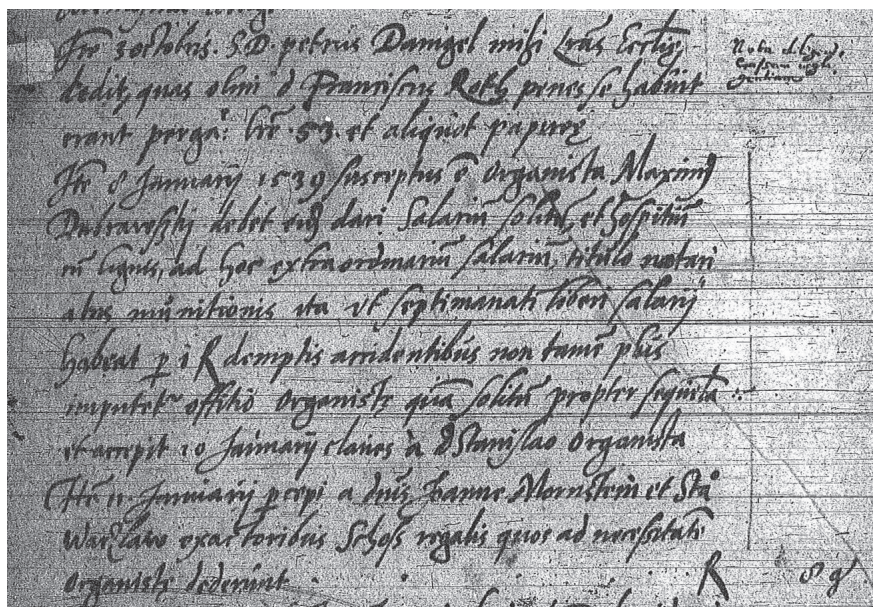

Il. 4. ANK Acta Eccl. et Monast. Crac., sygn. 3343, część Regestrum certorum censuum p. I4: „[...] 8 stycznia I539 przyjęty został organista Maksym Dubrawski, należy dać mu zwyczajowe wynagrodzenie i mieszkanie [zaopatrzone] w drewno opałowe, do tego dodatkowe wynagrodzenie z tytułu prawomocnego zatwierdzenia, tak, by miał co tydzień jeden floren wynagrodzenia wolnego od podatku. Poza sytuacjami wyjątkowymi niech nie obarcza się stanowiska organisty niczym ponad to, co należy do jego zwykłych obowiązków. Io stycznia otrzymał klucze od pana Stanisława organisty [...]”.

Nie wiemy, czy tylko biegłość w sztuce stanowiła o tak wysokim wynagrodzeniu. Maksym pobierał je przez niewiele ponad półtora roku, bowiem najpewniej to jego pogrzebu dotyczy notatka z i9 VIII I540 r. ${ }^{81}$ (zob. il. 5). Wpis ten przeoczył Chybiński, który ponadto w swych ekscerptach mylnie odczytał imię z omawianego tu źró-

79 Senaccy urzędnicy skarbowi.

80 ANK 3343 Regestrum censorum censuum, p. I6-17; A. Chybiński, „Z dziejów”, op. cit., s. I02.

8I ANK 3343 Regestrum distributorum, p. 7. Podobieństwo form „Dubrawski” i „Dobrawer” w połączeniu z identycznym, dość charakterystycznym imieniem, daje podstawę do uznania tożsamości postaci. W tej części źródła Maksym odnotowany jest jeszcze we wpisach z marca I54O r. (p. 5: „Maximo organistae iuxta contractum [...] f. $\left.8^{\prime \prime}\right)$. 


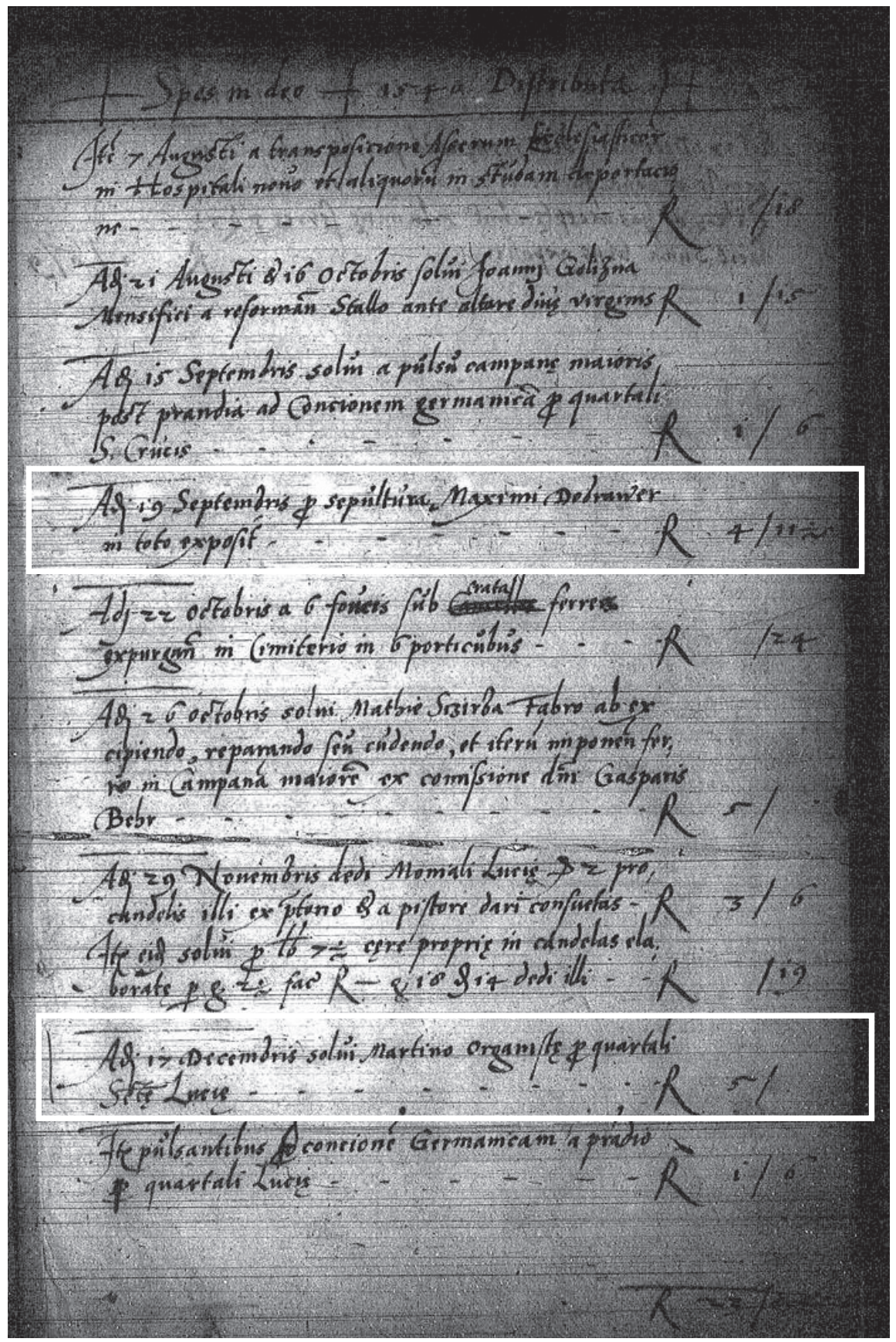

Il. 5. ANK Acta Eccl. et Monast. Crac., sygn. 3343, część Regestrum distributorum p. 7: „Dnia I9 września na pogrzeb Maksyma Dobrawera wydano w całości 4 fl. II gr.”; [...] „Dnia 17 grudnia wypłaciłem Marcinowi organiście za kwartał św. Łucji fl. 5”. 
dła jako „Marcin”, po czym połączył je z nazwiskiem „Dubrawski” i, tworząc nową - nieistniejącą - postać, orzekł, że „Marcin Dubrawski pozostał na tym stanowisku co najmniej do r. $1545^{\prime \prime 2}$.

I540-45 - Marcin (Martinus); pierwsze wynagrodzenie otrzymał w grudniu I540 r. (zob. il. 5) i przez kolejnych pięć lat otrzymywał je regularnie w stałej wysokości pięciu florenów kwartalnie ${ }^{83}$. Jeśli jest tożsamy z organistą Marcinem, wymienianym później w rachunkach miejskich z 1. 1549-56 (patrz dalej), to najprawdopodobniej jest też tożsamy ze wspomnianym wcześniej Marcinem Andreopolitą.

I543 - Bartłomiej (Bartholomaeus), określony w źródle jako „organista”, ale w kontekście jakichś prac wykonywanych przy instrumencie ${ }^{84}$, a nie uposażenia (w I543 r. w wykazach wypłat figuruje tylko Marcin); jego aktywność jako muzyka nie jest potwierdzona w innych źródłach.

Następne źródła zawierające interesujące nas zapiski, to kilka lat późniejsze książki rachunkowe rady miejskiej z l. I549 i 1551-56, gdzie w rubrykach „Praetorii necessaria” odnotowywano wypłaty dla ówczesnego organisty „templi S. Mariae"85.

I549-56 - Marcin; według postanowienia rady z I549 r. otrzymywał rocznie siedem marek i 24 groszy (= I2 flor.) z dodatkiem pięciu marek (= 8 flor.) na mieszkanie (zob. il. 6), gwarantowanych nawet w przypadku nadania mu jakiegoś kościelnego beneficjum ${ }^{86}$; źródła dają podstawę do wnioskowania, że chodzi tu o Marcina Andreopolitę, który pomimo angażu na dwór królewski w 1552 r., pozostawał jeszcze cztery lata przy kościele Mariackim z racji zobowiązań, a i później był z nim związany, m.in. przez zajmowanie lokum w domu zwanym „Turcia” ${ }^{87}$.

82 A. Chybiński, „Z dziejów”, op. cit., s. Ioz. Później autor podawał już właściwe daty dotyczące Dubrawskiego, czyli 1539-40, por.: A. Chybiński, Stownik muzyków, op. cit., s. 24. W źródle zapis imienia jest czytelny i nie pozostawia wątpliwości, że chodzi o Maksyma, a jego następca Marcin notowany jest tam bez nazwiska.

83 ANK 3343 Regestrum distributorum, p. 9, II, I2, I3, I4, I5, I6, I7, I8, 20, 2I, 22, 24, 26, 29.

84 Zob. przyp. 38.

85 ANK Consul. Crac., sygn. 442, p. I9; Perc. et distr. Crac., sygn. I6I3 p. I64, I6I4 p. I55, I6I5 p. I60, I6I6 p. I64, I6I7 p. I62, I6I8 p. I60. Ponadto w tomie sygn. I6I2, p. I78 jest notatka z jesieni 1548 r. o wypłacie czterech marek z dodatkiem dwóch marek i 24 groszy na mieszkanie dla organisty „Templi S. Mariae” (bez podania imienia).

86 ANK, sygn. 442, p. I9 („,...] Ita tamen q[uam]q[uam] primum Consulatus eundem Martinum organista[m] aliquo beneficio Ecclesiastico dotaverint et conderit tunc quoq[ue] eidem Martino tales sup[ra] additi I2 floreni deb[ebunt] cursus aditionis amplius numerari”. Warto zwrócić uwagę, że rada miasta opiera się tu na prawie prezenty na kościelne beneficja.

87 E. Zwolińska, „O Marcinie Andreopolicie”, op. cit., s. I42-I43. Wskazane tam źródła mogę uzupełnić podaną przez Bolesława Przybyszewskiego wzmianką o Marcinie („ecclesiae parochialis Beatae Virginis Maria in circulo Cracoviensi organista”) z 1550 r. (Wypisy źródtowe [...] I545-I550, op. cit., s. 3II, poz. 2582) oraz dokumentem z Archiwum Bazyliki Mariackiej (dalej ABMar), sygn. XXXVIII, k. 2I, gdzie „Martinus Musicus Regius” wymieniony jest wśród osób piszących w I57I r. do władz w sprawie domu „Turcia”. 


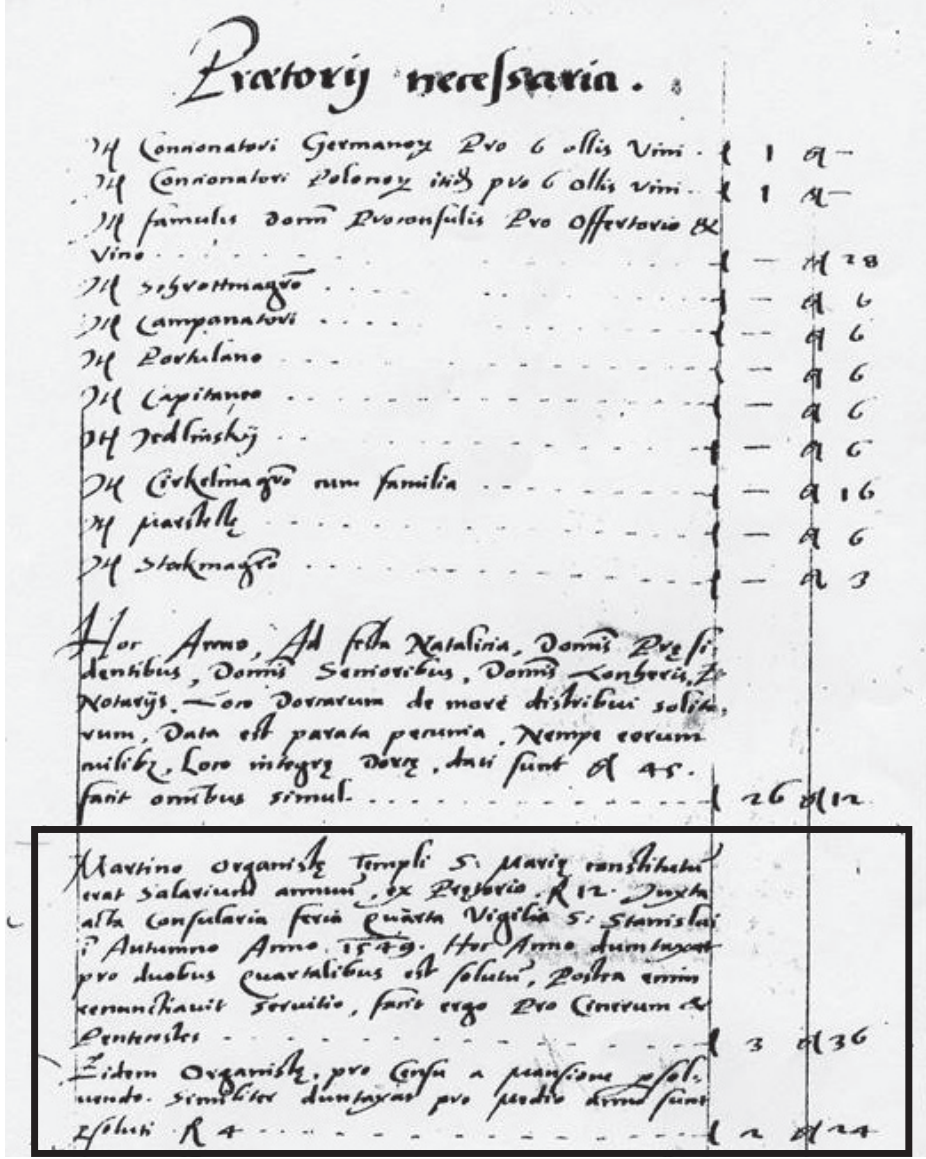

Il. 6. ANK Perc. et distr. Crac., sygn. I618, p. I60, I556: „Marcinowi organiście świątyni S. Mariae zostało przyznane roczne wynagrodzenie w wysokości I2 florenów, zgodnie z dokumentami rady miejskiej ze środy, w przeddzień św. Stanisława w jesieni 1549 roku. W obecnym roku [I556] wypłacono jedynie za dwa kwartały, po tym jak zrezygnował ze służby, zatem za kwartał Środy Popielcowej i Zielonych Świąt, co czyni 3 marki 36 groszy. Temuż organiście za czynsz na mieszkanie zapłacono podobnie za pół roku 4 floreny [czyli] 2 marki 24 grosze”.

W kwestii wynagrodzeń mariackich organistów należy dodać, że były one wolne od podatku i uzupełniane zwyczajową kwotą ośmiu florenów rocznie od bractwa Wniebowzięcia Najświętszej Marii Panny (jest ona uwzględniona m.in. w cytowanej wyżej zapisce o nowym kontrakcie z Dubrawskim) oraz - od I535 r. - dwudziestu ośmiu florenów wypłacanych na Wielkanoc z obligacji na jednej z kamienic w rynku ${ }^{88}$. Nie wiadomo

88 Chodzi o kamienicę „pod Murzynem”, zob.: A. Chybiński, „Z dziejów”, op. cit., s. Io3; Elżbieta Piwowarczyk, „Kościół Mariacki w Krakowie w świetle wizytacji Radziwiłłowskiej z roku I599”, w: Stromata Historica in honorem Romani Mariae Zawadzki”, red. Jacek Urban, Kraków 2006, s. I59. 
jednak dokładnie, z jakim zakresem obowiązków łączyło się wtedy stanowisko organistowskie, pewne informacje pochodzą dopiero ze źródła z końca stulecia, tzw. wizytacji Radziwiłłowskiej (wymieniono tam grę podczas mszy roratnich, podczas sumy w dni świąteczne, w niedzielę Wielkanocną, w Zielone Świątki, na porannej mszy w Boże Narodzenie, w oktawach świąt na mszach z procesjami z Najświętszym Sakramentem oraz na nabożeństwach czterdziestogodzinnych ${ }^{89}$ ). Co do sposobu włączania dźwięku organów w tok liturgii wypada przyjąć, że normą była ówczesna technika alternatim, czyli współdziałanie ze śpiewem liturgicznym. Zatem kolejne pytania dotyczą śpiewu w Mariackiej świątyni, a źródła kierują uwagę w stronę erygowanego w interesującym nas półwieczu kolegium mansjonarzy „nowej fundacji”. Dla dopełnienia tematu organistów warto jeszcze wspomnieć o przynależnym do Mariackiej parafii kościele św. Barbary, gdzie wówczas byli zatrudnieni: Wawrzyniec z Krosna („Laurencius de Crosno, organista ad sanctam Barbaram in Cracovia”, I526), Florian („Florianus organista ad sanctam Barbaram Cracovie”, I529) oraz Maksymilian („Maximilianus organista ecclesiae Sancte Barbare Cracovie", I549, I550)90.

\section{MANSJONARZE}

Zdaniem historyków, w świątyni Mariackiej była wówczas sprawowana - podobnie jak w wawelskiej katedrze - „nieustająca służba Boża”9I. Jednak wobec braku źródeł muzycznych nie da się obecnie wiele powiedzieć o ważnym elemencie tej służby, jakim był śpiew liturgiczny, i wypada przyjąć ogólne założenie, że rozbrzmiewająca w tym półwieczu w farze monodia chorałowa była zgodna z krakowskim rytem, znanym z ksiąg liturgicznych zachowanych w innych świątyniach miasta ${ }^{92}$. W literaturze przytacza się zwykle dwie informacje szczegółowe z ksiąg rachunkowych: wcześniejszą, jeszcze z XV w., dotyczącą rocznej wypłaty czterech marek dla mariackiego kantora za śpiew Salve Regina ${ }^{93}$, oraz odnotowane w połowie następnego stulecia

89 Podaję za: E. Piwowarczyk, „Kościół Mariacki”, op. cit., s. I59.

90 Wawrzyniec układał się z Urbanem altarystą w kościele Mariackim w sprawie „certos carminibus: Sub tuum praesidium [...], Ortus de Polonia super discantum et Da pacem, Domine” (Wypisy źródtowe [...] I526-I529, op. cit., s. I3-I4, poz. I9); Florian zaciągał dług, dając w zastaw księgę „tabulaturam in se continentis" (ibid., s. I49, poz. 295); informacje o Maksymilianie zob.: Wypisy źródtowe [...] I545-I550, op. cit., s. I45, poz. $24 \mathrm{I} 3$ oraz s. 288 , poz. 2529.

9I E. Piwowarczyk, Dzieje kościota, op. cit. s. I22.

92 O obszernym niegdyś zasobie kodeksów liturgicznych kościoła Mariackiego świadczą dawne inwentarze, zob. np.: E. Piwowarczyk, Dzieje kościota, op. cit., s. I68-I76; tejże, „Kościół Mariacki”, op. cit., s. I5I. Badając problem, dotarłam jedynie do zachowanych w zbiorach Biblioteki Książąt Czartoryskich/Muzeum Narodowego w Krakowie dwóch mszałów proweniencji mariackiej: pierwszy z nich, z datą „I540” na oprawie, pochodził z kaplicy cechu kuśnierzy, jest zapisany neumami gotyckimi (BC/MNK, sygn. 667), drugi zatytułowany na oprawie „Missale Cracovien”, jest prawdopodobnie późniejszy (choć w katalogu datowany na wiek XV (BC/MNK, sygn. 668).

93 "Cantor templi a decantatione Salve Regina singulis annis [...]” - podaję za: Kodeks dyplomatyczny miasta Krakowa I257-I506, cz. 2, 3, 4, wyd. Franciszek Piekosiński, Kraków I882 (= Monumenta medii aevi historica res gestas Poloniae illustrantia 7), s. 765. Z zapiski w źródle dotyczącym mariackiego 
wynagrodzenie dla kantora i dzwonników mariackich ${ }^{94}$ za udział w piątkowych komemoracjach męki Pańskiej95. Bardziej ogólny charakter mają ówczesne wzmianki o śpiewie duchowieństwa kościoła; najwięcej danych przynoszą dokumenty dotyczące działalności mariackich mansjonarzy.

W omawianym półwieczu duchowieństwo parafii Mariackiej obejmowało kilka grup o różnym zakresie działalności, byli to: wikariusze, altaryści, mansjonarze ${ }^{96}$. Przygotowano też w tym czasie, opierając się na zapisie testamentowym Piotra Salomona, projekt powołania kolegium psałterzystów do nieustannego śpiewu psalmów przed Najświętszym Sakramentem, ale kolegium to podjęło aktywną działalność dopiero po uzyskaniu kolejnego legatu pod koniec XVI w. ${ }^{97}$. Również z końca stulecia pochodzi informacja, że do zadań wikariuszy należało odprawianie w ważniejsze święta nabożeństw ze śpiewem scholarów ${ }^{98}$. Najliczniejsze było grono altarystów, odprawiających msze przy powierzonych im ołtarzach świątyni ${ }^{99}$. Część mariackich altarii była pod patronatem rady miejskiej i ich beneficjenci tworzyli osobną

bractwa wynika, że Salve Regina śpiewano przed obrazem Najświętszej Marii Panny, usytuowanym przy chrzcielnicy (członkowie bractwa winni dostarczać świece do oświetlenia tego obrazu: „Item durch das gancz adwent und durch dy gancze ffaste zal man burnen of der crone dy do mit dem Marie der iungfraw henget bey dem tawffsteyne [in?] allen Salve regina XII lichte [...]”, BJ, rkp. sygn. 2365, f. 3r).

94 Roczne wypłaty dla dzwonnika mariackiego odnotowywano też w wykazach „Praetorii necessaria” - zob. górna część il. 6. W niniejszym artykule pomijam sprawę dzwonników, chociaż w niektórych publikacjach są oni wzmiankowani przy muzykach, zob. np. Barbara Brzezińska, „Muzycy i muzyka w przyszpitalnym bractwie Ducha Św. w Krakowie (I540-1563)", Muzyka 25 (1980) nr 3, s. II6; Katarzyna Spurgjasz, Muzycy $w$ późnośredniowiecznym i wczesnonowożytnym Krakowie (I350-I550), Uniwersytet Warszawski $20 \mathrm{I2}$ (niepublikowana praca magisterska), aneks z wykazem muzyków s. 76-89.

95 „Census pro cantore et campanatoribus templi S. Mariae in circulo Crac. propterea, quod singulis ferÿs sextis decantantur Tenebrae factae et pulsetur campana magna in commemorationem Passionis et mortis Domini nostri Ihesu Christi extat descriptus in actis consularibus, feria secunda ante festum s. Laurentÿ anno 1554" - Kodeks dyplomatyczny, op. cit., s. 766. Na podstawie wzmianki w późniejszym Przewodniku przypisywanym Piotrowi Hiacyntowi Pruszczowi można przyjąć, że i w interesującym nas półwieczu odbywało się to przed ołtarzem Św. Krzyża („tu bywają grane pasye w każdy piątek przez rok cały", zob.: Przewodnik, abo kościotów krakowskich i rzeczy w nich widzenia i wiedzenia godnych krótkie opisanie, I wyd. Kraków I603, podaję za późniejszym przedrukiem: Klejnoty stotecznego miasta Krakowa albo kościoty [...] przez Piotra Hiacynta Pruszcza krótko opisane. Wydanie K.J. Turowskiego, Kraków I86I (= Biblioteka Polska seria V/42-43), s. 58.

96 Była też grupa tzw. gracjalistów, sprawujących posługę w podległym mariackiej parafii kościele św. Jana.

97 Wilhelm Gąsiorowski, Kościót Archipresbiterialny N.P. Maryi w Krakowie, opisat wedtug źródet archiwalnych tegoż kościota ..., Kraków I878, s. 85; Edmund Długopolski, Katalog kościoła N.P. Maryi w Krakowie, Kraków I9I6, s. 24-25; E. Piwowarczyk, Dzieje kościota, op. cit., s. I83-I84. Niezależnie od zwłoki z inauguracją działania tego kolegium (projekt pochodzi z 1535 r., legat pozwalający na podjęcie działalności - z I59I r.), psalmy z oczywistych względów rozbrzmiewały w farze - w cytowanych wyżej rachunkach zachowała się wzmianka z I543 r. o wynagrodzeniu niejakiego magistra Tomasza za śpiew psałterza („I543 [27 marca?] „,solui Mgro Thomae pro hac septimana pterista a Cantacione Psalterÿ", ANK 3343 część Distributa, p. 18).

98 Odnotowano to we wspomnianej już wizytacji Radziwiłłowskiej z 1599 r.; E. Piwowarczyk, „Kościół Mariacki", op. cit., s. 153 .

99 Niestety brak informacji, czy były to msze czytane, czy również śpiewane. Na temat instytucji altarii zob.: Józef Szymański, „Altaria”, w: Encyklopedia Katolicka, t. I, Lublin I985, szp. 387. 


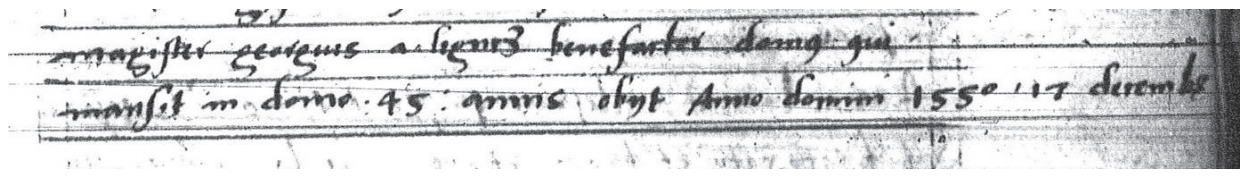

Il. 7. ANK Acta Eccl. et Monast. Crac., sygn. 336I p. I4I: „Magister Jerzy z Legnicy, dobroczyńca domu, w którym mieszkał czterdzieści pięć lat, zmarł roku Pańskiego 1550 I7 grudnia”.

grupę, mieszkającą w przeznaczonym dla nich domu. Warto o tym wspomnieć ze względu na Jerzego Libana, bowiem najpewniej jego dotyczy źródłowa informacja o magistrze Jerzym z Legnicy, który z domem altarystów związany był przez czterdzieści pięć lat aż do śmierci w I550 r. ${ }^{100}$ (zob. il. 7), a był beneficjentem głównej altarii w kościele św. Barbary oraz drugiej altarii św. Aleksego w kaplicy usytuowanej pod południową wieżą fary ${ }^{\mathrm{IoI}}$. Stałe lokum przy parafii mieli też - zgodnie ze swą nazwą - mansjonarze (mansio - pobyt, mieszkanie) i właśnie wśród im stawianych zadań liturgicznych wymieniany jest śpiew podczas nabożeństw.

W mariackiej parafii były wówczas dwie korporacje mansjonarzy rezydujących w odrębnych domach. Jedna, powołana jeszcze w połowie XV w. przez Teodoryka Weinricha w liczbie pięciu duchownych (w ciągu stulecia liczba ta wzrosła do ośmiu), była powiązana z kościołem św. Barbary i tam miała odprawiać officium de Beata $^{\mathrm{IO} 2}$. Druga grupa to zobligowane do sprawowania liturgii w głównej świątyni parafii kolegium mansjonarzy, którego działalność podlegała regułom określonym w fundacjach z I5IO i I527 r.; pierwszą z nich zatwierdził biskup Jan Konarski, kolejną - Piotr Tomicki. Wcześniejsza z tych fundacji dotyczyła mianowania na tzw. stypendium odręcznym dwunastu duchownych z prawem do mieszkania w domu przy mariackim $\mathrm{cmentarzu}^{\mathrm{IO} 3}$, a kilkanaście lat później powołane zostało kolegium

IOo Roczną datę śmierci Libana (I550) podał już niegdyś Wilhelm Gąsiorowski (Kościót Archipresbiterialny, op. cit, s. 28).

IOI „Altare summum in eccl. S. Barbare in circulo Crac. cuius possessor honorandus Georgius de Lyegnycz, qui iur-t etc.”; „Altare tit. S. Alexii secundi ministerii in eccl. par. B. Marie Virginis sub turri in Crac[ovia] cuius posessor prefatus magister Georgius iur-t”, podaję za: Księga dochodów beneficjów diecezji krakowskiej z I529 roku (tzw. Liber retaxationum), wyd. Zofia Leszczyńska-Skrętowa, Wrocław 1968, s. 2I (w źródle f. 8Ir). Pierwsza z tych altarii miała wartość Is marek, druga - I2 marek i I2 groszy w skali rocznej.

IO2 E. Długopolski, op. cit., s. 25-26; Jerzy Paszendo, Kościót św. Barbary w Krakowie z domem zakonnym księży jezuitów, Kraków-Wrocław 1985 (= Biblioteka Krakowska I25), s. 28-29. Dokładniejsze informacje o zadaniach tej grupy mansjonarzy pochodzą z końca XVI w., kiedy przeniesiono ich do świątyni Mariackiej po przekazaniu kościoła św. Barbary jezuitom, zob.: E. Piwowarczyk, „Kościół Mariacki”, op. cit., s. $164-165$.

IO3 Siedemnastowieczna kopia aktu fundacji z I5ıo r. znajduje się w rękopisie ANK Acta Eccl. et Monasteri Crac., sygn. 3368. Prawo do użytkowania połowy tego domu mansjonarze otrzymali już wcześniej od rajcy Jana Reguły, całość dostali dzięki donacji Piotra Salomona, który zapisał im też procent od sumy Iooo florenów z żup solnych, zob.: Waldemar Bukowski, „Salomonowie herbu Łabędź. Ze studiów nad patrycjatem krakowskim wieków średnich", w: Cracovia - Polonia - Europa. Studia z dziejów średniowiecza ofiarowane Jerzemu Wyrozumskiemu w sześćdziesiąta piąta rocznicę urodzin i czterdziestolecie 
obejmujące jedenastu członków mianowanych dożywotnio („mansionarii perpetui”). Dla zilustrowania zasad działania i zadań tego kolegium podaję najważniejsze ustalenia z aktu erekcyjnego z 1527 r. (niektóre z nich są zbieżne z regułami fundacji wcześniejszej); oryginał dokumentu oznaczony jako dypl. perg. sygn. 212 znajduje się w Archiwum Bazyliki Mariackiej w Krakowie (dalej ABMar), zachowały się też jego późniejsze odpisy ${ }^{104}$.

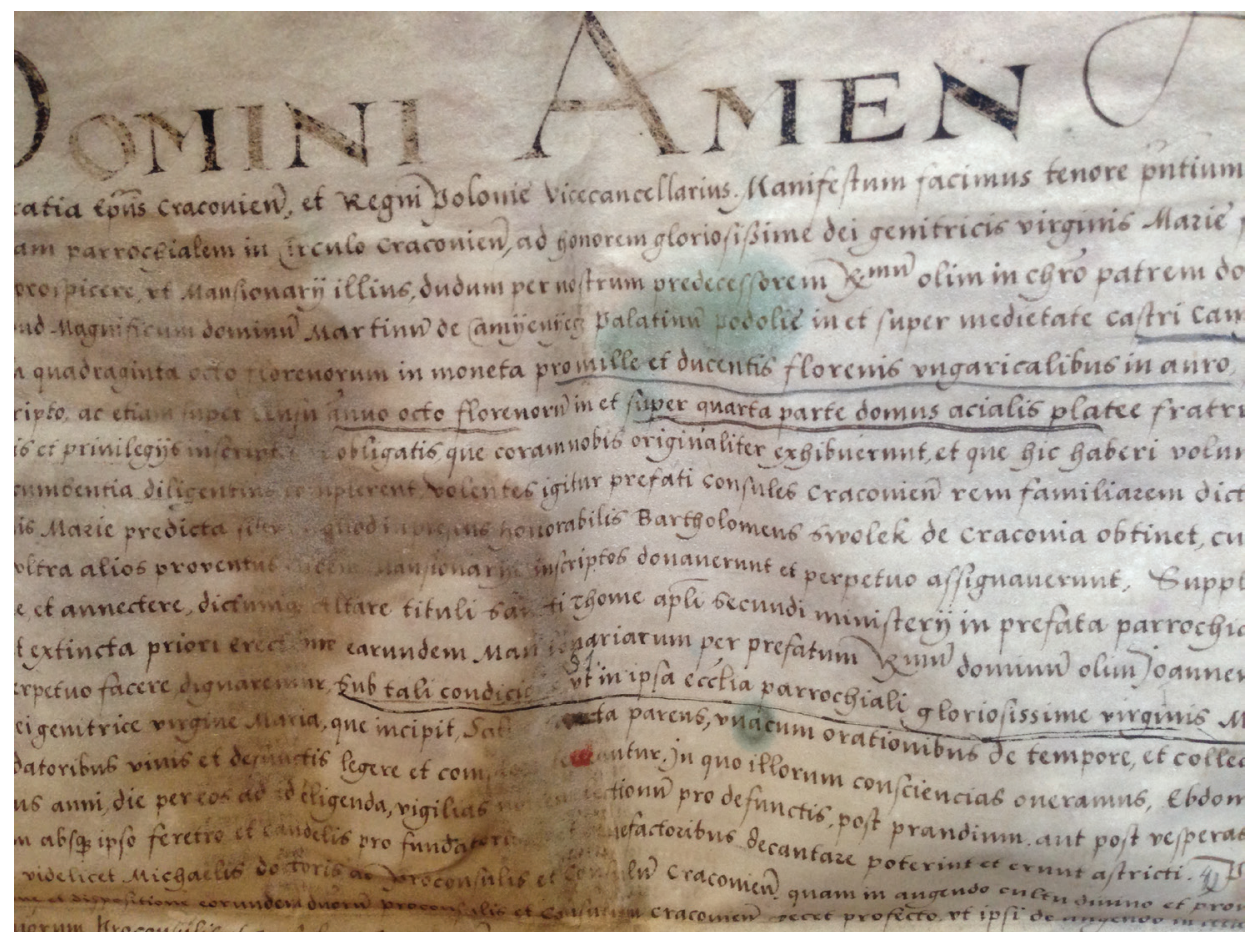

Il. 8. Archiwum Bazyliki Mariackiej, dypl. perg. sygn. 2I2: fragment aktu fundacyjnego z I527 r.; wymiary całości dokumentu ok. $67 \mathrm{~cm}$ x 85 cm. Za zgodą Bazyliki Mariackiej w Krakowie.

- Podane w dokumencie cele fundacji to podtrzymanie splendoru świątyni, podjęcie i wykonanie nowej ordynacji dotyczącej liturgii oraz kontynuacja dzieła poprzedników z jednoczesnym poszerzeniem środków dla kolegium i zagwaranto-

pracy naukowej, red. Waldemar Bukowski et al., Kraków 1995, s. 135. Zatrudnienie „odręczne” oznaczało mianowanie do określonych czynności z możliwością odwołania. Należy dodać, że mansjonarze działali przy farze już wcześniej, a wymienione tu fundacje były zgodne z szesnastowieczną tendencją do łączenia tych duchownych w kolegia, zob.: Stanisław Tymosz, „Mansjonarz”, w: Encyklopedia Katolicka, t. II, Lublin 2006, szp. II8I.

I04 Znane siedemnastowieczne kopie aktu: ABMar, sygn. CXLIX, fasc. I09, poz. I32, ANK Acta Eccl. et Monasteri Crac., sygn. 3367. Dziękuję najuprzejmiej Pani dr Agacie Wolskiej z Archiwum Bazyliki Mariackiej za udostępnienie skanów oryginału aktu erekcyjnego oraz za wskazówki dotyczące innych źródeł z zasobów tego Archiwum. 
waniu stałego zatrudnienia jego członków ${ }^{105}$; jako inicjatorów fundacji wskazano tu Michała z Lublina ${ }^{106}$ oraz burmistrza i rajców krakowskich.

- Podstawę materialną działalności kolegium stanowiły liczne donacje prywatne oraz przekazane mu w 1527 r. dodatkowo dochody z altarii św. Tomasza ${ }^{107}$. Jako prawnych opiekunów dla ośmiu członków kolegium wskazano w akcie rajców krakowskich, a reprezentowanie trzech pozostałych powierzono Michałowi z Lublina (zob. il. Io; nb. patronat doktora Michała nie trwał długo, bowiem zmarł on w I 528 r. i również ci trzej mansjonarze zostali objęci patronatem rady miejskiej).

- Spośród członków kolegium wyłaniany był senior zatwierdzany przez biskupa oraz dwóch mansjonarzy odpowiedzialnych za pobieranie funduszy z przyznanych dotacji. Do zadań seniora należało m.in. wskazanie członkom mieszkania w domu korporacji (każdemu dwie izby), stalli w chórze, miejsca w kapitularzu; miał on też czuwać nad wypełnianiem obowiązków i przestrzeganiem zasad korzystania z dobra wspólnego. Podane w akcie wynagrodzenie dla członków kolegium miało wynosić osiem marek ${ }^{108}$, a Michałowi z Lublina, który włożył w to dzieło wiele starań i otaczał je szczególną opieką, przyznano 25 marek $^{109}$.

IOS „Ad perpetuam rei memoriam [...] nos, Petrus de Thomice Dei gratia episcopus Cracoviensis et Regni Poloni vicecancellarius manifestum facimus [...] quia venerabiles et famati domini Michael de Lublin decretorum doctor [...] nec non proconsul et consules Cracovienses animadvertentes Ecclesiam Parochialem in civiculo Cracoviensi, ad honorem Dei Genitricis MV fundatam inter alias parochiales ecclesias in civitate Cracoviensi esse insigniorem multis rebus et ornamentis partim a se, partim a praedecessoribus decenter provisam cupientesque aliam in divinis officiis ordinationem in illaque fieri et prospicere [...]", ANK 3367, p. Io. „[...] extincta priori erectione eorundem mansionariorum per praefatum reverendum dominum olim Ioannem episcopum facta, undecim mansionarios perpetuos, quos hactenus manuales et amovibiles fuerant, denuo erigere, facere, creare et erigere dignaremur”, ANK 3367, p. I2. Na obecnym etapie badań nie mogę skomentować wymienionej w akcie nowej ordynacji w sprawie nabożeństw.

Io6 Michał z Lublina (zm. I528 r.) - doktor prawa kanonicznego po studiach na Akademii Krakowskiej i uniwersytetach we Włoszech, dziekan kolegiaty w Kurzelowie, fundator kolegiaty św. Anny w Krakowie, zob.: Ryszard Skrzyniarz, „Michał z Lublina”, w: Encyklopedia Katolicka, t. I2, Lublin 2008, szp. 833.

IO7 ANK 3367, p. II-I2. Wśród fundatorów wymienionych imiennie w akcie jest m.in. wojewoda podolski Marcin z Kamieńca, Piotr Ligęza z Chrzanowa czy kuśnierz Maciej Noszka. Kopiariusz zapisów dla mansjonarzy, obejmujący okres od I527 r. do XVIII w., zachował się w ANK Acta Eccl. et Monasteri Crac. pod sygn. 3369 .

IO8 „Qui quidem undecim mansionarii praedicti moderni et pro tempore existentes habebunt et pro se quilibet percipiet ratione benefici sui octo marcas pecuniarum monetae et numeri Polonicalis consueti de pecuniis censuum suprascriptorum et aliorum in praesentibus literis non expressorum eis, ut praemissum est, ad eorum sustentationem donatorum et obligatorum", ANK 3367, p. I5. Z treści tego fragmentu aktu nie wynika, czy chodzi o wynagrodzenie roczne, czy kwartalne, ale z dalszej części, dotyczącej Michała z Lublina (zob. następny przyp.) można wnosić, że o roczne. Franciszek Piekosiński (Kodeks dyplomatyczny, op. cit., s. 759) podaje inną kwotę, mianowicie 7 marek 24 groszy w skali kwartalnej (czyli 30 marek rocznie). Dla porównania: uposażenie rorantystów wawelskich wynosiło dla prebendariuszy 20 marek rocznie, a prepozyt dostawał 43 marki, zob.: Tomasz M.M. Czepiel, Music at the Royal Court and Chapel in Poland c. I543-I600, New York-London I996, s. 24-25; Elżbieta Zwolińska, „...voce sonora, iucunda et cantu figurato. O muzyce "między ołtarzem a tronem» w kaplicy Zygmuntowskiej”, w: Klejnot w koronie. 65o-lecie konsekracji katedry krakowskiej, red. Jacek Urban, Ewelina Zych, Kraków 2017 (= Biblioteka Kapitulna na Wawelu Io), s. 396.

I09 „Quia autem praefatus venerabilis dominus Michael Lublin [...] pro fundandis et erigendis doctis mansionariis non parum operae et studii sui impendit, et in magna parte fructuum illos auxit, reservavimus 
- Przyjęcie w poczet kolegium następowało po przeegzaminowaniu kandydata przez mansjonarzy i ich seniora w zakresie obyczajności i umiejętności śpiewu (podkr. E.Z.), a następnie poddaniu go tygodniowej próbie ${ }^{\text {Iо }}$.

- Obowiązki kolegium zostały w akcie fundacyjnym określone następująco (podaję odpowiedni fragment w polskim przekładzie, tekst źródłowy zob. il. 9):

[...] wzmiankowani mansjonarze zostali zobowiązani do odśpiewania we własnej osobie przez wszystkie godziny całego oficjum, to jest: nabożeństwa porannego wraz ze zwyczajowymi laudami i modlitwami, prymy, tercji, seksty, nony, nieszporów i komplety, a także wczesnej mszy o niepokalanej Bożej Rodzicielce Dziewicy Maryi, którą rozpoczyna Salve Sancta Parens, razem ze stosownymi modlitwami oraz kolekty za fundatorów i dobroczyńców w poszczególnych dniach w przyszłości. Każdy z wymienionych mansjonarzy będzie też zobowiązany do wybrania i odprawienia w poszczególnych tygodniach jednej mszy za żyjących i zmarłych fundatorów - sam lub przez innych odpowiednich kapłanów. Tym obarczamy ich sumienia, za wyjątkiem hebdomadariusza, który podczas owego tygodnia, kiedy będzie pełnił swe obowiązki, powinien być zwolniony z odprawiania tejże mszy ${ }^{\text {III }}$. Ponadto za swego życia wzmiankowani mansjonarze będą zobligowani, by w każdym kwartale w dniu przez nich na to wybranym odśpiewać wigilie z dziewięcioma czytaniami za zmarłych, po obiedzie lub po nieszporach wikaryjskich - wedle tego, co zda im się stosowniejsze; w dniu następnym zaś w miejsce mszy o Świętej Dziewicy Maryi, ustawiwszy w chórze mary żałobne i zapaliwszy cztery świece woskowe, mszę za zmarłych fundatorów i dobroczyńców. Ponadto wzmiankowani mansjonarze niechaj będą zobowiązani do wypełnienia wszystkich obowiązków, już wcześniej włączonych [dotyczących] ołtarza Świętego Tomasza Apostoła w tymże kościele Świętej Marii ${ }^{12}$.

illi cum consensus praefatorum dominorum proconsulis et consulum Cracoviensium et proventibus reservamus pro eius victu viginti quinque marcam pecuniarum monetae et numeri Polonici, quas de censibus praefatis mansionariis ascriptis singulis annis ad vitam suam dumtaxat libere et sine quovis impedimento praefatorum mansionariorum percipient, et ubi ei visum fuerit convertet gaudebitque mensa communi una cum mansionariis", ANK 3367, p. I5.

IIO „Decernentes eosdem undecim mansionarios deinceps pro perpetuis beneficiis censeri et reputari debere, patronosque illorum, respective presbyterum seu presbyteros idoneos quoties illos vel aliquem illorum per cessus vel decessum vacare contigerit conferre, et examinatum vel examinatos prius per mansionarios praedictos, semper illorum seniorem, de moribus, de vita et cantu, per unam hebdomadam deinde approbatum, nobis vel successoribus nostris episcopis Cracoviensibus vel eorum vicariis pro tempore existentibus ad instituendum praesentare debere", ANK 3367, p. I4.

III Hebdomadariusz - duchowny wyznaczony w danym tygodniu do pełnienia nadzoru nad nabożeństwami (m.in. prowadzący liturgię godzin). W akcie wcześniejszej fundacji z I IIO r. podkreślono jednak, że mszę Salve Sancta Parens winien on śpiewać z innymi mansjonarzami („Volumus autem, ut hebdomadarius, pro tempore existens, sit liber et exceptus a lectura dictarum missarum, sed ipse hebdomadarius missam de Beata Virgine Salve Sancta Parens, alta voce una cum praefatis presbiteris mansionariis domum supra dictam inhabitantibus decantabunt", ANK 3368, p. II).

II2 ANK 3367, p. I2-I3. Powierzony mansjonarzom ołtarz św. Tomasza znajdował się w nawie południowej (obecnie jest tu ołtarz z obrazem św. Karola Boromeusza), w pobliżu zamykającego nawę renesansowego ganku połączonego z kaplicą Kaufmanów. 


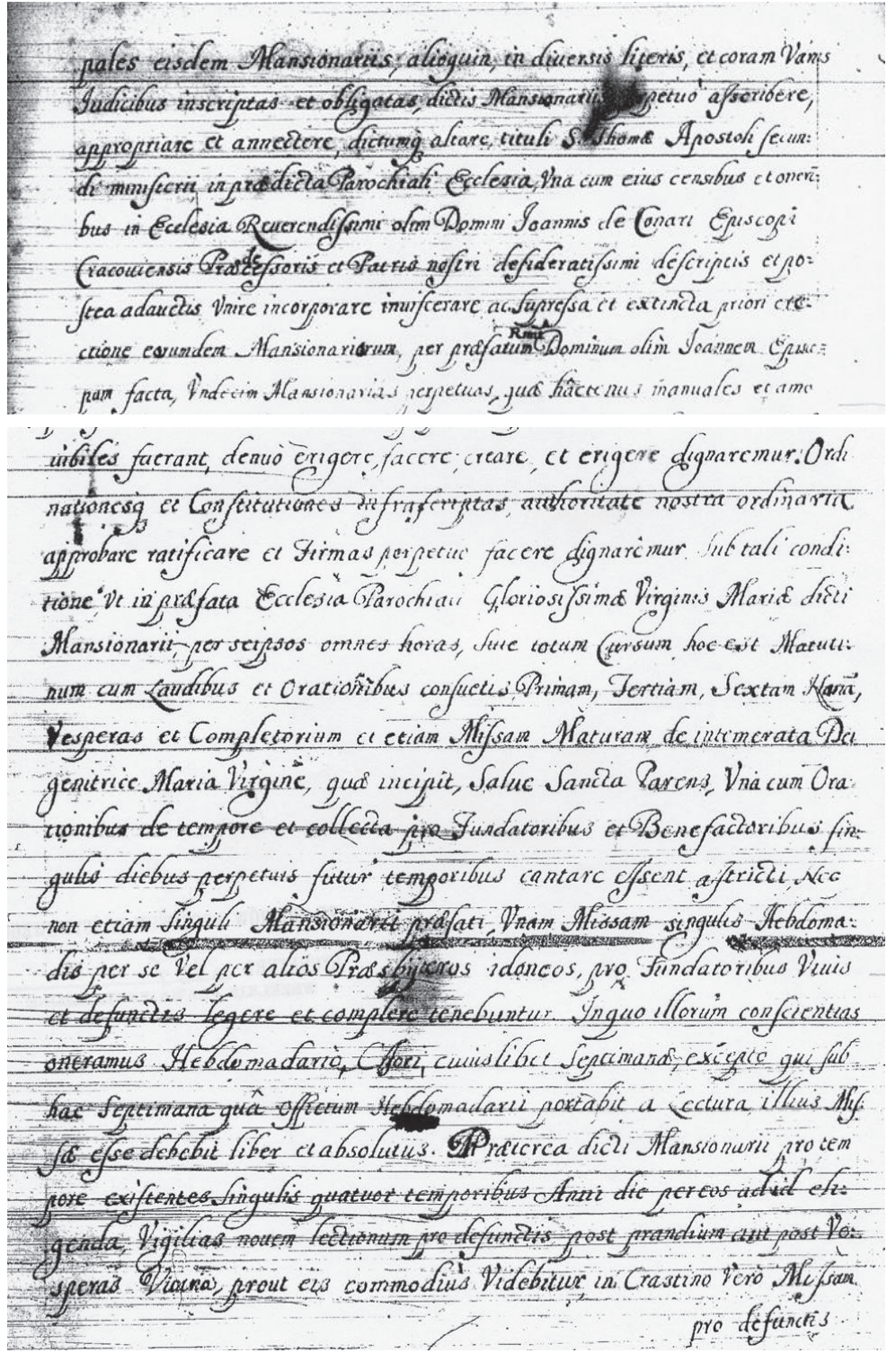

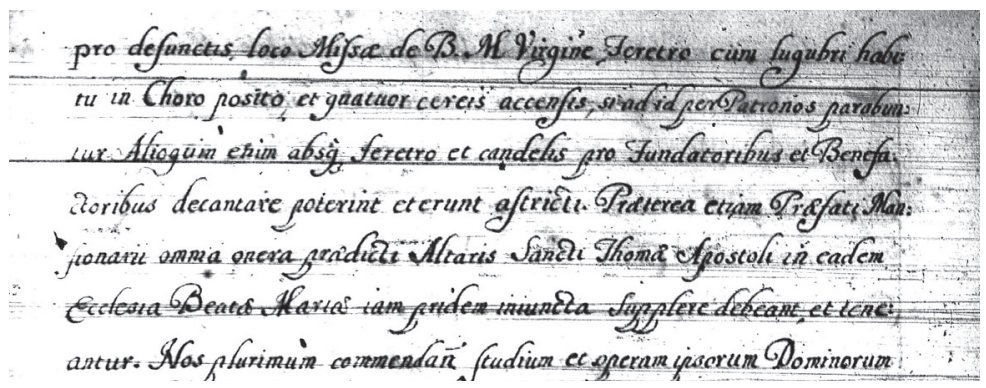

Il. 9. ANK Acta Eccl. et Monast. Crac., sygn. 3367, p. I2-I3. 
Wymienione w dokumencie wymagania wobec mansjonarzy miały charakter indywidualny lub zespołowy - te drugie były ściśle związane z obowiązkiem śpiewu, którego umiejętność była warunkiem przyjęcia do kolegium. Informacje źródłowe składają się tu na pewien ogólny obraz zadań wokalnych kolegium, jednak odnośnie do sposobu realizacji tych zadań, ewokują kilka domniemań i pytań, na które w obecnym stanie badań nie ma jasnych odpowiedzi.

Pierwsze pytanie dotyczyłoby miejsca odprawiania przez kolegium officium i mszy Salve Sancta parens. Chętnie przyjęlibyśmy dziś za pewnik, że fundacja miała zapewnić wysoki poziom oprawy liturgii sprawowanej przed ołtarzem Mariackim. Taki wniosek można wysnuć z podanej w akcie wskazówki, że cokwartalne msze za zmarłych dobroczyńców mają być odśpiewane „in choro” zamiast mszy maryjnej (podkr. E.Z.). Mogłoby o tym też świadczyć użyte w dokumencie określenie „missa matura”, oznaczające pierwszą z mszy odprawianych w chórze (poranną) ${ }^{\mathrm{II}}$. Jednak dalszy fragment tekstu, dotyczący spraw finansowych, osłabia nieco to przekonanie: „[mansjonarze] dadzą corocznie półtorej marki na zakup świec woskowych do ołtarza, przy którym rzeczona msza Błogosławionej Panny Marii będzie przez nich w poszczególnych dniach odśpiewana"I4 - zawarta tu informacja nie jest jednoznaczna, a próba przyjęcia założenia, że używane w źródłach określenie „mansjonarze Wniebowzięcia Najświętszej Marii Panny” wiązało ich z głównym ołtarzem byłaby zawodna, bowiem w farze istniało wówczas więcej ołtarzy pod tym wezwaniem ${ }^{\text {IIs }}$.

Zadania wokalne określono w źródle jako „cantare” i „decantare”, co zapewne odnosiło się do monodii chorałowej (ale chyba nie wykluczało polifonii ${ }^{16}$ ). Odpowiedzi na pytanie o kształt tej śpiewanej wówczas liturgii można dziś szukać jedynie w źródle dużo późniejszym, mianowicie w zachowanym w Archiwum Bazyliki Mariackiej kodeksie Missae votivae de Sancta Maria et pro festis eiusdem beatissimae Virginis [...] pro usu [...] Reverendorum Patr[or] um Mansionariorum Assumptionis Beatae M. Virginis [...], sporządzonym w 1729 r. ${ }^{\mathrm{II7}}$. Kodeks zawiera maryjne msze

II3 John Harper, op. cit. (zob. przyp. 9), s. I53, 316.

II4 „Unam vero marcam cum media pro comparandis candelis cereis ad altare, apud quod missa praedicta de B Virgine Maria singulis diebus per eos decantabitur, singulis annis dabunt et assignabunt", ANK 3367 , p. 15 .

IIs Chodzi o ołtarz w kaplicy św. Aleksego, ołtarz w kaplicy brackiej - oba w części przeciwległej do ołtarza głównego; taką tytulaturą opatrzony był też ołtarz w kaplicy Weinrichowskiej.

II6 Warto zauważyć, że w pierwszym akcie fundacyjnym wawelskich rorantystów (I543 r.) określa się ich zadanie wokalne jako „psallere” i „decantare”, a określenie „cantu figurato” pojawia się tylko raz, w części sygnowanej przez króla (pełen tekst tego aktu w: T.M.M. Czepiel, op. cit., s. I88-207). Ponadto, choć w katedrze czynna była grupa mansjonarzy, również rorantyści określani są w tym dokumencie jako „mansionarii” (zamiennie z nazwami: „praebendarii”, „praesbiterii” czy „sacerdotes”), co można tłumaczyć faktem posiadania przez nich własnego domu na Wawelu.

II7 ABMar, rkp. sygn. 85I. Pełen tytuł księgi: Missae votivae de Sancta Maria et pro festis eiusdem beatissimae Virginis. Ex Graduali Romano Dessumptae ac emendate descriptae cum suo ordinario pro usu et commoditate Admodum Reverendorum Patr[or]um Mansionariorum Assumptionis Beatae M. Virginis. In Caemeterio Manentium Cracoviae Anno Domini MDCCXXIX. 
wotywne na kolejne pory roku kościelnego, następnie proprium missarum świąt maryjnych (Conceptio, Purificatio, Annuntiatio, Visitatio, Dedicatio S. Mariae ad Nives, Assumptio, Nativitas, Praesentatio), a w końcowej części msze: in Commemoratione Omnium Fidelium Defunctorum, de SS. Trinitate, de SS ${ }^{\text {ma }}$ Eucharistiae Sacramento, de Passione Domini. Być może własnością mansjonarzy była nieznana dziś księga, opisana podczas wizytacji fary w I599 r. jako „Officium śpiewane w kościele Panny Marii zapisano w kodeksie częściowo pergaminowym”"I8.

Wokalna oprawa oficjum i mszy Salve Sancta parens należała wówczas do zadań mansjonarzy w różnych świątyniach, śpiewali je również mansjonarze krakowskiej katedry w kaplicy Narodzenia Najświętszej Marii Panny ${ }^{\mathrm{II}}$. Należy wspomnieć, że wówczas w tej kaplicy na Wawelu znajdowały się organy ${ }^{\mathrm{I2O}}$, co umożliwiało praktykę współdziałania śpiewaków i organisty przy odprawianiu nabożeństw (określaną dziś jako wspomniana technika alternatim). Zatem przy podjęciu próby odtworzenia początkowego przebiegu powierzonej mansjonarzom liturgii mszalnej - tak w katedrze, jak i w farze - wydaje się uprawnione sięgnięcie po zapisane w tabulaturze organowej Jana z Lublina w latach czterdziestych XVI w. Officium Virginis Mariae Salve Sancta parens, na które składa się mszalny introit i Kyrie de Sancta Maria ${ }^{\mathrm{I21}}$. Było ono niewątpliwie przeznaczone do wykonania alternatim: fragmenty do grania przez organistę to w introicie antyfona Salve Sancta parens i wersus „Senciant omnes hominum innanie", zaś w Kyrie - odcinki pierwszy i trzeci Kyrie, drugi Christe oraz Kyrie ultimum. Segmenty instrumentalne łączą się tu z liturgią poprzez użyte w nich melodie chorału, wkomponowane jako cantus firmus w konstrukcję czterogłosową ${ }^{\text {I22 }}$. Pozostałe części introitu i Kyrie wypełniał śpiew: w introicie powtórzenie antyfony Salve i dok-

II8 E. Piwowarczyk, „Kościół Mariacki”, op. cit., s. I5I.

II9 „Tenentur praefati octo mansionarii ad decantandum officium de Assumptione Beatae Virginis una cum missa cantata diebus singulis Salve sancta parens [...]", podaję za: Inwentarz katedry wawelskiej z roku I563, opr. Adam Bochnak, Kraków 1979 (= Źródła do dziejów Wawelu ıo), s. 198, w źródle f. I37r. Tę katedralną kaplicę wybrała królowa Bona na swe prywatne oratorium i na początku lat trzydziestych XVI w. wprowadzono tam odpowiednie zmiany architektoniczne (wybudowano ganek i lącznik z zachodnim skrzydłem zamku), by monarchini mogła modlić się w odosobnieniu i słuchać mszy odprawianej przez mansjonarzy, zob.: Krzysztof J. Czyżewski, „Katedra krakowska jako kościół królewski. Wybrane zagadnienia”, w: Klejnot w koronie, op. cit., s. 193 i nast. Dziś kaplica ta nosi nazwę kaplicy Batorego.

I20 Warto dodać, że mansjonarzem katedralnym był wymieniony tu wcześniej organmistrz Jan Niedziela, zob. Krakowskie środowisko artystyczne, op. cit., s. I88; J. Rajman, „Organy w katedrze”, op. cit., s. 175.

I2I Biblioteka Polskiej Akademii Nauk / Polskiej Akademii Umiejętności w Krakowie, rkp. sygn. 1716, f. I85v-I87v. Edycje źródła: Tabulatura organowa Jana z Lublina. Indeks tematyczny. Indeks alfabetyczny. Facsimile, wyd. Krystyna Wilkowska-Chomińska, Kraków 1964 (= Monumenta Musicae in Polonia, seria B, t. I); Tabulatura Joannis de Lublin. Ad faciendum cantum choralem. Fundamentum. Ad faciendum correcturam, wyd. i przekł. polski Elżbieta Witkowska-Zaremba, Warszawa 2015 (= Monumenta Musicae in Polonia, seria C); Johannes of Lublin. Tablature of Keyboard Music, wyd. John R. White, American Institute of Musicology 1964-1966 (= Corpus of Early Keyboard Music 6).

I22 Transkrypcja organowych części tego Officium zob.: Johannes of Lublin, op. cit., t. I, s. 70-72, t. II, s. 35-37 (jak widać, podzielono w tej edycji spójną całość na dwie części). Nb. introit Salve został wskazany w poprzedzającym tabulaturę traktacie Ad faciendum cantum choralem jako przykład właściwego organowego opracowania cantus firmus; zob.: Elżbieta Witkowska-Zaremba, „Wstęp”, w: Tabulatura Joannis de Lublin, op. cit., s. 22. 
sologia Gloria Patri et Filio, a w Kyrie - kolejno odcinki: drugi Kyrie, pierwszy i trzeci Christe i powrót Kyrie. Jak wiadomo, przy wykonaniach alternatim odcinki wokalne mogły mieć postać zarówno monodyczną, jak i polifoniczną ${ }^{\mathrm{I23}}$, ale pytanie o sposób przyjęty przez mariackie kolegium pozostaje w obecnym stanie wiedzy otwarte (można tu jedynie zaznaczyć, że liczba mansjonarzy i stawiany im wymóg umiejętności śpiewu nie pozwalają wykluczyć stosowania wielogłosowości).

Przy założeniu, że w dźwiękowej oprawie liturgii sprawowanej przez mariackich mansjonarzy uczestniczył organista, pojawia się pytanie o zasadę ich współdziałania. Wiadomo, że w owym czasie organista kościelny bywał włączany organizacyjnie do grupy duchownych, czego przykład mamy w wawelskiej katedrze, gdzie był przyporządkowany do kolegium psałterzystów ${ }^{\mathrm{I24}}$, oraz w kolegiacie św. Michała w Lublinie - tu przewidziano dla niego miejsce w erygowanym w I 536 r. kolegium mansjonarzy ${ }^{125}$. W przypadku mansjonarzy i organistów mariackich dostępne dziś źródła nie wskazują takiej zależności, ale - jak wcześniej podano - odnośnie do istotnych dla tematu lat dwudziestych i trzydziestych XVI w. jest w kwestii organistów pewna luka. Wiadomo natomiast, kto wchodził w skład „nowej” korporacji mansjonarzy, bowiem w końcowej części dokumentu erekcyjnego z I 527 r. zamieszczono ich imienny wykaz (początkowy fragment poniższego tekstu, zob. il. Io):

Co zaś do tychże jedenastu mansjonarzy, zacnych mężów, panów Stanisława z Gorlicy, Macieja z Kalisza, Pawła z Frysztaka, Wawrzyńca z Czchowa, Stanisława z Łańcuta, Szymona ze Skoczowa, Jana ze Strzelec, Jana z Lublina, Szymona z Cierniechowa, Walentego z Krakowa i Bartłomieja Szwołka, to reprezentowanie tychże panów powierzyliśmy i oddaliśmy doktorowi Michałowi i burmistrzowi, i rajcom miasta Krakowa, jako ich prawnym opiekunom. Powierzamy i oddajemy im także obecnie troskę, nadzór i zarząd nad dobrami duchowymi i doczesnymi tychże mansjonarzy, powtórnie zatwierdzając fundację ${ }^{\mathrm{I2} 6}$.

I23 Zob. np.: Barbara Brzezińska, Repertuar polskich tabulatur organowych, op. cit., s. 97-I03; Andrzej Szadejko, „Praktyka alternatim w muzyce organowej”, w: Musica Sacra, t. 3, Gdańsk 2007 (= Prace specjalne Akademii Muzycznej im. S. Moniuszki w Gdańsku 73), passim. Interesującą próbę rekonstrukcji sposobu łączenia fragmentów organowych z polifonią wokalną przedstawił niedawno Grzegorz Kos: „“Kyrie paschale” in Polish organ tablatures of the I6th century - problems of style and attribution", Muzyka 6I (2016) nr 3, s. 7 i nast. Zob. też dyskusje na temat ówczesnej techniki alternatim w: Martin Staehelin, Die Messen Heinrich Isaacs, Bern-Stuttgart 1977, t. 3, s. 15-16 i II6.

I24 Sprawa znana m.in. w przypadku Mikołaja z Chrzanowa, zob.: A. Chybiński, „Mikołaj z Chrzanowa”, op. cit., nr 20, s. 3 i nast.; Dorota Żurek, „Mikołaj z Chrzanowa. Nowe ustalenia w sprawie losów organisty i kompozytora”, Muzyka 63 (2018) nr I, s. 75-86; Elżbieta Zwolińska, „Mikołaj z Chrzanowa”, op. cit., s. IOI-IO2. Zob. też przyp. I2O.

I25 Kolegium erygował biskup Jan Latalski, powstało z fundacji rodziny Spyczyńskich. Składało się z prepozyta i sześciu mansjonarzy, przy czym jeden z nich powinien być organistą ,ad nutum amovibilis”, a pozostali „perpetui”, zob.: „Kolegium mansjonarzy i psałterzystów w Kolegiacie św. Michała w Lublinie”, opr. Grzegorz Kondrasiuk, strona http://teatrnn.pl/leksykon/artykuly/kolegium-mansjonarzy-i-psalterzystoww-kolegiacie-sw-michala-w-lublinie, dostęp 23 IV 2018.

I26 ABMar dypl. perg., sygn. 2I2 (tu z powodu ubytków pergaminu niewidoczne nazwiska Szymona ze Skoczowa i Jana z Lublina); ABMar CXLIX, fasc. I09, nr 132; ANK 3367, p. 17 (lista pełna, ponadto 


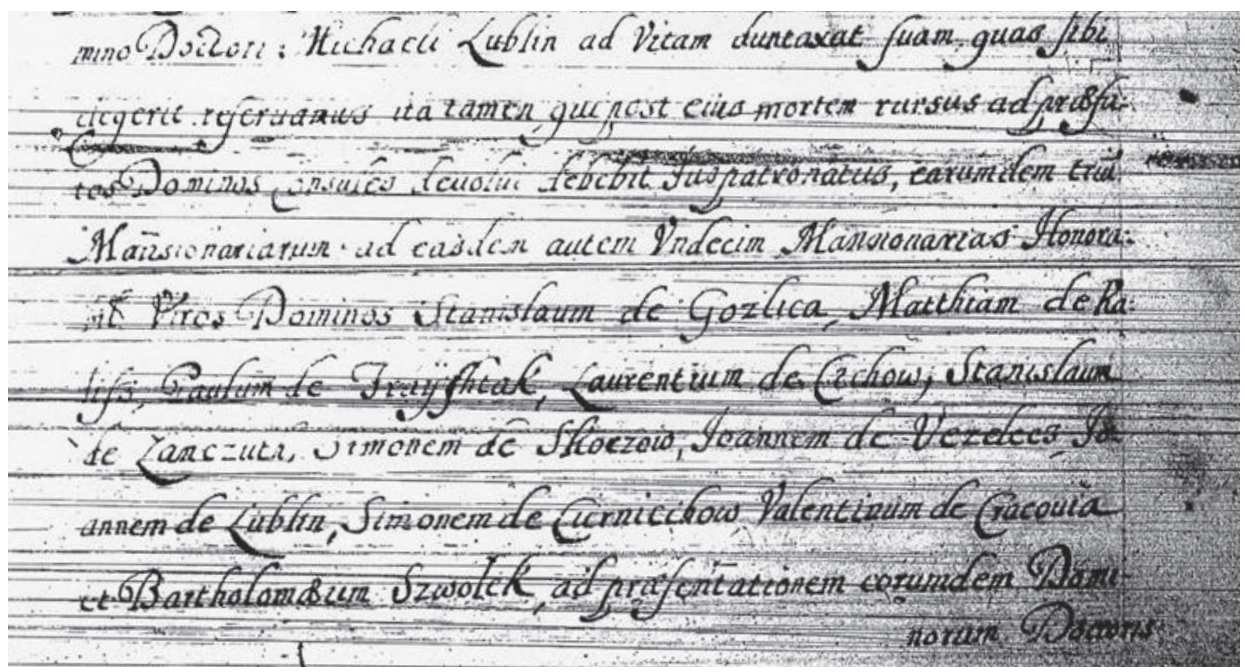

Il. Io. ANK Acta Eccl. et Monast. Crac., sygn. 3367, p. 17. Górna część wykadrowanego tekstu dotyczy prawnej opieki nad członkami kolegium, sygnalizowanej wyżej na s. 25.

Seniorem kolegium był wówczas wymieniony na początku wykazu Stanisław z Gorlic (Gorlica), odnotowywany w zapiskach dotyczących odbioru należnych mansjonarzom funduszy ${ }^{\mathrm{I} 27}$. Jednak uwagę muzykologa przyciaga w oczywisty sposób inne nazwisko z tego wykazu, kojarzące się z najobszerniejszym w skali europejskiej omawianego półwiecza rękopisem z muzyką organową, czyli wymienioną wcześniej tabulaturą Jana z Lublina, zwaną wymiennie kraśnicką ${ }^{\mathrm{I28}}$. Skojarzenie to zachęca do postawienia ostrożnego pytania o prawdopodobieństwo tożsamości mansjonarza fary Mariackiej z postacią związaną później z klasztorem kanoników regularnych w Kraśniku, zwłaszcza że w opinii badaczy fragmenty Janowej tabulatury mogły powstać w Krakowie ${ }^{\mathrm{I2}}$. Sprawę tę podjęła niedawno Elżbieta Witkowska-Zaremba przy edycji teoretyczno-dydaktycznej części tego cennego zabytku w serii Monumenta Musicae in Polonia ${ }^{130}$.

w dalszej części tego źródła powtórzona w obszernym, utrzymanym w porządku chronologicznym wykazie osób, „qui ad hanc communitatem accesserint”, gdzie z datą I566 wymieniony jest też „Reverendus Dominus Martinus Andreopolitanus Musicus S. M. R.”, ANK 3367, p. 2I-22).

I27 Ksiega dochodów, op. cit., s. I48-I49; Archiwum Kurii Metropolitalnej w Krakowie (dalej AKMK), Acta

Off. sygn. 48, p. 58I-582; Wypisy źródtowe [...] I530-I533, op. cit., s. I47, poz. 694; Z. Noga, op. cit., s. 62 (przyp. IOI).

I28 Biblioteka Polskiej Akademii Nauk / Polskiej Akademii Umiejętności w Krakowie, rkp. sygn. 1716 (edycje źródła zob. przyp. I2I).

I29 Paweł Gancarczyk, „Uwagi kodykologiczne o tabulaturze Jana z Lublina (I537-I538)”, Muzyka 4I (1996) nr 3, s. 45-58.

I30 Elżbieta Witkowska-Zaremba, „Wstęp”, w: Tabulatura Joannis de Lublin, op. cit., s. 9-Io. 
JAN Z LUBLINA

Dla muzykologów dość długo jedyną informacją o tej postaci był tytuł tabulatury, wskazujący na więź jej posesora z klasztorem kanoników regularnych w Kraśniku w I54O r. (Tabulatura Ioannis de Lyvblyn Canonic [orum] Regularium de Crasnyk I540). Wskazywano na możliwość identyfikacji kraśnickiego kanonika z Janem z Lublina, który w I499 r. uzyskał na krakowskiej akademii tytuł magistra, lub z jego imiennikiem, kończącym tę uczelnię dziewięć lat później ze stopniem bakałarza ${ }^{131}$. Osobą Jana interesował się też Wacław Urban, ale zgromadzone materiały źródłowe nie dały mu podstaw do ustaleń w tej kwestii ${ }^{132}$. Istotną informację przyniosły kilkanaście lat temu badania Ewy Zielińskiej, która dotarła do tzw. nekrologu kraśnickiego (spisywanego w klasztorze bożociałków ${ }^{\mathrm{T} 33}$ na podkrakowskim Kazimierzu, macierzystym dla zgromadzenia w Kraśniku) ze wzmianką, że I4 XI I552 r. zmarł tam „dominus Joannes a Lublin"134, co najpewniej odnosi się do omawianej tu postaci. Otwarte pozostaje jednak pytanie o początek pobytu Jana w Kraśniku, zwłaszcza w świetle popartych badaniami domniemań, że powstanie genetycznie starszej części jego tabulatury (I537-39) można wiązać z Krakowem ${ }^{135}$ i że stamtąd prawdopodobnie pochodzą źródła, z których czerpał twórca tej niezwykłej kolekcji. Wydaje się ponadto, że część dydaktyczna zbioru mogła być w zamyśle autora adresowana do szerszego środowiska, niż kraśnickie.

Idąc tropem tych domniemań i szukając śladów powiązań posesora tabulatury przed 1540 r. z Krakowem, należało w pierwszym rzędzie zwrócić uwagę na wspomniany konwent kanoników regularnych laterańskich przy kościele Bożego Ciała, kultywujący od lat liturgię z bogatą oprawą muzyczną ${ }^{\mathrm{r} 36}$, ale choć w zachowanych dokumentach tego zgromadzenia odnotowano takie nazwisko, to jednak zapisany tam Jan „de Loeblin” zmarł w I492 r. ${ }^{137}$. Świadectwem krakowskich powiązań mu-

I3I Piotr Poźniak, „Jan z Lublina”, w: Encyklopedia Muzyczna PWM, red. Elżbieta Dziębowska, t. 4, Kraków 1993, s. 408-409.

I32 „Dysponuję źródłowymi informacjami o kilku Janach z Lublina (m.in. o jednym ślepym księdzu), lecz nic nie potwierdza ich tożsamości z autorem tabulatury”, zob.: Wacław Urban, „Notatki źródłowe o muzykach polskich w XVI w.", Muzyka 32 (1987) nr I, s. 59 (przyp. 8).

I33 Jedna z popularnych nazw kanoników ze zgromadzeń krakowskich, przyjętych dziś powszechnie w literaturze historycznej; kanonicy regularni z kościoła pod wezwaniem Bożego Ciała określani byli mianem bożociałków, z kościoła św. Ducha - duchaków, a z kościoła św. Marka - marków, zob. m.in.: Mirosław Daniluk, „Kanonicy regularni”, w: Encyklopedia Katolicka, t. 8, Lublin 2000, szp. 594.

I34 Ewa Zielińska, Kultura intelektualna kanoników regularnych z klasztoru w Kraśniku w latach I469-I563, Lublin 2002, s. I46. Fakt ten odnotowano też zwyczajowo w nekrologu klasztoru macierzystego, ale tylko z imieniem Joannes (ibid.). Inny zakonnik o tym imieniu - magister Johannes de Lublin - był czynny w Kraśniku na początku XVI w. (ibid., s. 65). Zob. też: E. Witkowska-Zaremba, „Wstęp”, op. cit., s. 9.

I35 P. Gancarczyk, op. cit., s. 53 i nast.

I36 Formy tej liturgii (m.in. takie gatunki śpiewu, jak „cantus - modulacio - accentuacio”) były obecne też w klasztorze w Kraśniku, zob.: E. Zielińska, op. cit., s. 40.

I37 Kazimierz Łatak, Kanonicy regularni laterańscy na Kazimierzu w Krakowie do końca XVI wieku, Ełk 1999, s. 166,255 . 
zycznych kraśnickiego organisty mogą być w pewnym zakresie konkordancje repertuarowe jego tabulatury ze źródłem z innego kanonickiego konwentu, mianowicie z tabulaturą z klasztoru św. Ducha ${ }^{138}$, ale i tu brak śladów bezpośredniego kontaktu. Wiadomo natomiast o Janie z Lublina, który według zachowanych dokumentów z 1. 1527-35 był związany z krakowską farą i ten fakt może być przedmiotem ostrożnej uwagi w przypadku pytań o biografię posesora tabulatury.

W archiwaliach mariackich „honorabilis Joannes de Lublin” jako członek kolegium „mansionariorum perpetuorum” wymieniony jest też w dokumencie z 1527 r., utrwalonym w późniejszym, siedemnastowiecznym odpisie ${ }^{\mathrm{I} 39}$. Z innych zachowanych źródeł wynika, że z farą Mariacką wiązało go ponadto beneficjum altarysty: w I528 r. uzyskał altarię pierwszego ministerium przynależną do ołtarza Wniebowzięcia Najświętszej Marii Panny, przejętą po mansjonarzu Stanisławie z Łańcuta ${ }^{\mathrm{I} 0}$. Beneficjum to nie było przypisane do głównego ołtarza świątyni ${ }^{\mathrm{I}}$, lecz do ołtarza w kaplicy ufundowanej w I435 r. przez wspomnianego już Teodora Weinricha (znanej też pod innymi, późniejszymi nazwami, np. Krabusowska, Remerowska, a obecnie pod wezwaniem św. Jana Nepomucena). Fakt posiadania tej altarii przez Jana potwierdzają jeszcze trzy nieco późniejsze źródła: wpis w tzw. Liber retaxationum z I529 r. ${ }^{\text {I42 }}$ oraz dwa wpisy w Acta officialia Archiwum Kurii Metropolitalnej w Krakowie $\mathrm{z}$ lat $\mathrm{I} 533^{\mathrm{I} 43}$ i $\mathrm{I} 535^{\mathrm{I} 44}$.

I38 Zob.: B. Brzezińska, Repertuar polskich tabulatur organowych, op. cit., passim.

I39 ABMar CXLIX fasc. I09, nr I3I (sporządzony 30 VIII I527 r. dokument dotyczył m.in. legatu dla mansjonarzy poczynionego przez Macieja z przydomkiem „Ave Maria”; inny wpis w sprawie tego legatu wskazuje B. Przybyszewski w: Wypisy źródtowe [...] I526-I529, op. cit., s. I30-I3I, poz. 257).

I40 AKMK Acta Episcopalia, sygn. I4, f. I6r; tekst wpisu zob.: E. Witkowska-Zaremba, „Wstęp”, op. cit., s. 9.

I4I Tak je interpretuje Elżbieta Piwowarczyk w pracy „Fundacje XV-wiecznych ołtarzy w kościele Mariackim w Krakowie i ich uposażenie do roku I529", Kraków 2004 (= Folia Historica Cracoviensia Io), s. 324, jednak we wskazanym przez nią źródle (Liber retaxationum, zob. przyp. Ioo) występuje imię księżnej zatorskiej Małgorzaty (Machny) jako fundatorki, co wskazywałoby na altarię w kaplicy Weinrichowskiej.

I42 „Altare tit. Assumptionis S.Mariae primi ministerii fundacionis ducis Machne in eccl. par. S. Marie in Crac cuius posessor honor. Joannes de Lvblin”, Księga dochodów, op. cit., s. 240 (w źródle f. I57r, podana tu wartość tej altarii to Io1/2 marki w skali rocznej).

I43 „Ascripcio census [...] altari tituli assumptionis beate Marie in capella Tetrich Vannrich [...] honorabilis Joannis de Lublin dicti altaris possesoris [...]”, wpis z datą I2 III I533 r., AKMK Acta Officialia, sygn. I3, p. 2I2-213. Za życzliwą pomoc w odnalezieniu tego zapisu dziękuję ks. mgr. Jarosławowi Raźnemu, Wicedyrektorowi Archiwum Kurii Metropolitalnej w Krakowie.

I44 "Venerabilis Nicolai Crabuss ad sanctam Annam plebani et altariste ad sanctam Mariam in Circulo Cracoviensi, Catherine Malcherowa et aliorum litis consorcium ex una et famatorum dominorum proconsulis et consulum Cracoviensium, ut et tanquam et collatorum altaris primi ministerii in Capella dicta vulgariter Crabussowska, necnon honorabilis Joannis de Lublyn in prefata capella altariste, de et super reffectione et restauracione tecti supra eandem capella destructi - decernimus [...]" - wpis z datą I II I535 r., AKMK Acta Officialia, sygn. 63, s. 209-2II (podaję za: Wypisy źródtowe [...] I534-I535, op. cit., s. 59, poz. 1216). Dokument dotyczy sporu o remont kaplicy, dalszy ciagg w thumaczeniu: „[...] postanawiamy, aby panowie burmistrz i rajcy i patroni, razem z samym panem Janem z Lublina, ich altarystą, strop nad tą właśnie kaplicą Krabusowską [...] wraz z Mikołajem i Katarzyną Krabusami oraz pozostałymi uczestnikami sporu odbudowali, odnowili lub też zgromadzili i przekazali [fundusze na ten cel], nadto wzmiankowany ołtarz przenieśli i przewieźli stamtąd na jeden miesiąc gdzie indziej, na mocy tego postanowienia [...]”. Niewykluczone, że ołtarz zmieniał miejsce już wcześniej - w dokumencie 
Nazwisko Jana z Lublina pojawia się jeszcze w różnych zapiskach źródłowych z tych lat, ale dotyczy innej postaci ${ }^{145}$. Natomiast z interesującym nas Janem - mansjonarzem i altarystą mariackim - łączy się być może jeszcze jeden zapis z I529 r.: „Mansionaria nove fundacionis in eccl. S. Barbare in circulo Crac. cuius possessor honor. Joannes de Lvblin [...]" ${ }^{\text {I46 }}$; przy takim domniemaniu wyłania się jednak pytanie, czy Jan mógł był łączyć obowiązki w obu mansjonarskich kolegiach parafii? W świetle zachowanych dokumentów, potwierdzających jego kontakt z farą w l. I527-35 odpowiedź nie jest łatwa i na razie pozostaje w sferze przypuszczeń, podobnie jak wcześniejsze losy tej postaci ${ }^{147}$ oraz okoliczności jej ewentualnego odejścia z tego środowiska pod koniec lat trzydziestych XVI wieku. Przy tym ostatnim domyśle warto mieć na uwadze możliwość niepewnego statusu Janowej altarii w kaplicy Krabusowskiej, jako że współprotektorka tego beneficjum, Katarzyna Malcherowa (zob. przyp. I44), wdowa po rajcy Melchiorze Weiglu, była postawiona przed sądem biskupim za apostazję i spalono ją na stosie na Małym Rynku w Krakowie w kwietniu 1539 r. ${ }^{148}$.

Poszukiwanie krakowskiego kontekstu tabulatury Jana z Lublina stwarza też możliwość szerszego spojrzenia na inne zagadki tego zabytku. Przykładem może być utrwalone tam imię „Valentinus”, opatrzone późniejszym, wyblakłym dopiskiem, odczytywanym jako wskazanie skryptora („scripsit”) ${ }^{\text {I49 }}$ lub ostatnio przez Ewę Zielińską - jako skrót odmiejscowego nazwiska późniejszego kraśnickiego organisty,

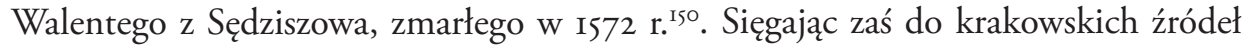
z interesujących nas lat, można wskazać inne postaci o tym imieniu, poczynając od figurującego obok Jana z Lublina na liście mariackich mansjonarzy Walentego z Krakowa (zob. il. Io), następnie Walentego - przeora bożociałków w I542 r. ${ }^{\text {I51 }}$, Walentego

z I528 r., cytowanym tu w przyp. I40, jest określony jako „ante capellam Melchior” (podkr. E.Z.), a w 533 r. wikariusz generalny udzielił rajcom krakowskim pozwolenia na przeniesienie go w pobliże stalli i ołtarza św. Szymona i Judy (Katalog Archiwum Aktów Dawnych miasta Krakowa. I. Dyplomy pergaminowe, Kraków 1907, s. I37, sygn. 506).

I45 Przybyszewski łączy je z postacią duchownego piastującego godności: kanonika opatowskiego, scholastyka mstyczowskiego, prebendarza kościoła św. Marii Magdaleny w Nasiechowicach i altarysty ołtarza św. Macieja w krakowskim kościele św. Szczepana, zob.: Wypisy źródtowe [...] I530-I533, op. cit., s. I43.

I46 Księga dochodów, op. cit., s. I6I (w źródle f. I08r); beneficjum wynosiło I6 marek rocznie (ibid.). Określenie „nove fundacionis” prawdopodobnie dotyczy ósmej mansjonarii u św. Barbary, ufundowanej w I5I9 r. przez Jakuba z Lublina, zob.: J. Paszendo, Kościót św. Barbary, op. cit., s. 29.

I47 Niewykluczone, że to on uzyskał w I508 r. wspomniany wyżej bakalaureat w Akademii Krakowskiej.

I48 Wypisy źródtowe [...] I534-I535, op. cit., s. 59, przyp. I; Z. Noga, op. cit., s. I82; W. Komorowski, A. Sudacka, op. cit., s. 83. Warto tu wspomnieć, że stosunek między fundatorem altarii a jej beneficjentem był oparty na zasadzie pełnej podległości, zob.: Józef Szymański, „Altaria”, op. cit., szp. 387.

I49 Na ten temat zob.: B. Brzezińska, Repertuar polskich tabulatur organowych, op. cit., s. 45.

I50 E. Zielińska, op. cit., s. 69. Według tej autorki, dopisek można odczytać jako „Sedis”.

I5I K. Łatak, op. cit., s. I67. A. Chybiński (Stownik muzyków, op. cit., s. I33) wymienia też związanego z tym konwentem w II poł. XVI w. organistę Walentego. Zob. też przyp. 25 w niniejszej pracy ze wzmianką o organiście Walentym od duchaków z końca XV wieku. 
subsignatora (pomocnika kantora) szkoły mariackiej ${ }^{152}$, dalej - mieszkającego w I547 r. w domu przy Szewskiej organistę Walentego ${ }^{\mathrm{I53}}$ i wreszcie organistę Walentego u św. Anny około roku $1548^{154}$ (być może tożsamego z poprzednim). Do kwestii innych zagadkowych imion i monogramów zamieszczonych w tabulaturze można zaś dodać informacje, że w I529 r. beneficjentem jednej z mariackich altarii był Mikołaj z Krakowa ${ }^{\mathrm{I} 5}$, a wicekantorem u duchaków w I550 r. - Mikołaj „Zardeczki” "I56

\section{KONFRATERNIA}

W opinii Andrzeja Dąbrówki, dawne bractwa tworzyły w granicach „parafii legalnej” parafie o charakterze „umownym”, dysponujące własną kaplicą i ołtarzem, związane z określonym kultem sprawowanym pod pieczą wybranego duchownego, patronujące też niekiedy własnym beneficjom ${ }^{157}$. Taką „subparafią” w Mariackiej farze była niewątpliwie wspominana już wcześniej elitarna konfraternia Wniebowzięcia Najświętszej Marii Panny („Fraternitas Sancte Marie”/„Bruderschaft Vnser Liben Frawen”), gromadząca się na nabożeństwa we własnym oratorium „inter turres”, wyróżniona m.in. papieskimi przywilejami odpustowymi ${ }^{158}$. Do tego patrycjuszowskiego grona należeli członkowie senatu, zamożni kupcy, starsi najzamożniejszych cechów; w dokumentach, dla podniesienia rangi stowarzyszenia, byli też wpisywani na pierwszym miejscu królowie ${ }^{\mathrm{I} 9}$. Podane niżej informacje o znaczącej roli muzyki w działaniach tej społeczności pochodzą z trzech źródeł: rękopisu Biblioteki Jagiellońskiej sygn. 2365 , zawierającego m.in. odnowiony statut bractwa i listę członków

I52 Walenty ze Zdżaru (I540 r.), podaję za: Jan Krukowski, Nauczyciele szkót parafialnych Krakowa w XVI wieku, Kraków 2007, s. 59, I7I. Mariackiego subsignatora Walentego z I532 r. wymienia też Wacław Urban, „Kantorzy i sukcentorzy szkolni diecezji krakowskiej w pierwszej połowie XVI wieku”, Muzyka 38 (I993) nr I, s. 90. O zakresie pojęć „kantor”, „wicekantor”, „signator”, „subsignator”, „sukcentor” zob.: W. Urban, „Kantorzy i sukcentorzy”, op. cit., s. 87; Remigiusz Pośpiech, „Funkcje kantora w tradycji muzycznej kościoła katolickiego na Śląsku", w: Complexus effectuum musicologiae. Studia Miroslao Perz septuagenario dedicata, red. Tomasz Jeż, Kraków 2003, s. I77-I79 (= Studia et dissertationes Instituti Musicologiae Universitatis Varsoviensis, seria B, t. I3) oraz J. Krukowski, op. cit. (passim, tu inna interpretacja).

I53 Wypisy źródtowe [...] I545-I550, op. cit., s. II7, poz. 2098.

I54 Wacław Urban, „Notatki źródłowe o muzykach polskich w XVI w.”, Muzyka 32 (I987) nr I, s. 58.

I55 „Altare tit. S. Marie Magdalene a secundi ministerii in eccl. Par. S. Marie Virginis Beatissime in circulo Crac. cuius possessor honor. Nicolaus de Crac[ovia] - Księga dochodów, op. cit., s. I2I (w źródle f. 8Ir); prawo patronatu nad tą altarią miała rada miejska, zob.: Z. Noga, op. cit., s. 225.

I56 J. Krukowski, op. cit., s. I73. „Nicolaus Zardeczki” pojawia się też w dopisku w inwentarzu katedry wawelskiej z I563 r. jako altarysta ołtarza św. Katarzyny w tej świątyni, zob.: Inwentarz katedry wawelskiej, op. cit., s. 2II, odsyłacz c.

I57 Andrzej Dąbrówka, Teatr i sacrum w średniowieczu. Religia - cywilizacja-estetyka, Toruń ${ }^{2}$ 20I3, s. 232. Zob. też: Katarzyna Morawska, Renesans I500-I600, Warszawa [I994] (= Historia muzyki polskiej 2), s. 7I.

I58 Informacje o konfraterni i jej dziejach są obecne w wielu publikacjach, zob. np.: Hanna Zaremska, Bractwa $w$ średniowiecznym Krakowie. Studium form społecznych życia religijnego, Wrocław-Warszawa-Kraków I977, s. 68, I22, I23; E. Piwowarczyk, Dzieje kościota, op. cit., s. II9; Andrzej Bruździński, „Bractwa religijne w siedemnastowiecznym Krakowie. Zarys problematyki”, w: Historia świadectwem czasów. Księdzu Profesorowi Markowi Tomaszowi Zahajkiewiczowi, red. Włodzimierz Bielak, Stanisław Tylus, Lublin 2006, s. I07-IO9; J. Rajman, „Unsere liebe Fraue”, op. cit., s. 63.

I59 A. Bruździński, op. cit., s. Io8. 
konfraterni w I48I r. oraz z osiemnastowiecznych rękopisów ANK 3362 i 3363, przekazujących też kopie dokumentów wcześniejszych, m.in. statutu z roku I4II.

Według piętnastowiecznych ustaleń, do nabożeństw brackich należały poranne msze sobotnie oraz kwartalne wigilie i msze żałobne; konfratrzy mieli też uczestniczyć w liturgii ważniejszych świąt (maryjnych i innych, zob. il. II); w zapisie z I48I r. jest też wzmianka o codziennym śpiewaniu Rorate podczas adwen$\mathrm{tu}^{\mathrm{I}}{ }^{60}$. W śpiewach konfraterni uczestniczyli za wynagrodzeniem kantor/signator, uczniowie (w liczbie siedmiu), nauczyciel ${ }^{161}$; wymieniony jest też - jak wcześniej wspomniano - organista fary ${ }^{162}$ (zob. il. I2). W kolejnych dziesięcioleciach było zapewne podobnie, bowiem w późniejszych archiwaliach zachowały się wzmianki o sobotnich mszach wotywnych do Najświętszej Marii Panny czy wigiliach $\mathrm{w}$ intencji zmarłych donatorów i członków bractwa ${ }^{163}$. W jednym z tych późniejszych źródeł jest nawet wzmianka o śpiewie polifonicznym (,solemniter cantari [...] cantu figurato et organario occinentibus"), ale znajduje się ona w ogólnym zapisie zadań konfraterni i na obecnym etapie badań nie mogę wskazać, jakiej fazy jej dziejów dotyczy ${ }^{164}$.

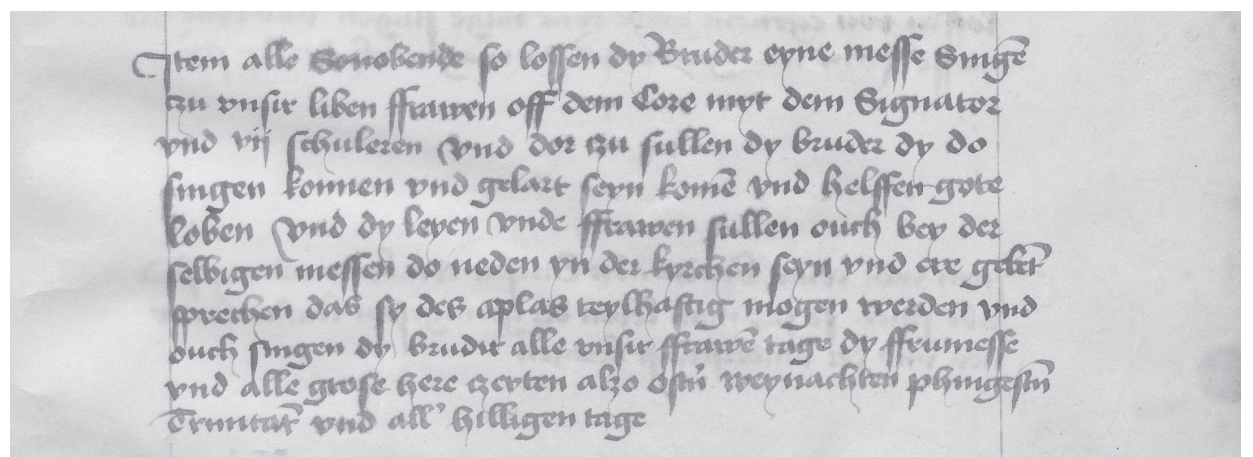

Il. II. Biblioteka Jagiellońska, rkp. sygn. 2365, f. 2r: „W każdą sobotę bracia mają śpiewać na chórze mszę do Matki Boskiej z signatorem i siedmioma uczniami [...] niech śpiewają ci, którzy umieją i niech tak pomogą chwalić Boga [...] Również kobiety winny być obecne i modlić się na tych mszach [...] Bracia winni też śpiewać wczesną mszę we wszystkie święta maryjne i wszystkie wielkie [święta] jak Boże Narodzenie, Zielone Święta, dzień św. Trójcy i inne”. Ta i kolejna reprodukcja za zgodą Biblioteki Jagiellońskiej w Krakowie.

I60 „Item alle bruder $[\ldots]$ in der Capella der bruderschafft do man zinget das Rorate teglich $[\ldots]$ durch das gancz advent", BJ 2365 , f. 3 r.

I6I „Item dem Cantor und den Schulern dÿ dÿ Frumessen singen alle Sonnabend [...] dem Schulmeyster [...] von der Vilgen czu singen [...]”, ibid., f. 7r. W źródle zastosowano wymiennie pojęcia „cantor” $\mathrm{i}$,signator”, co potwierdza interpretację Urbana i Pośpiecha (zob. przyp. 152).

162 „Item dem Organisten [...]”, ibid. W zachowanym w tym samym źródle wykazie członków bractwa widnieje „Nicolaus organista” (ibid., f. IIr), zob. też przyp. 70.

I63 ANK Acta Eccl. et Monasteri Crac., sygn. 3362, 3363.

I64 ANK, sygn. 3363 , s. 2. Cytat pochodzi z opatrzonego datą I7II Descriptio inscriptionum confraternitatis Assumptionis B. Mariae Virginis [...] excerpto ex libro visitaionis [...] per Casimirum a Eubna Eubieński episcopum Crac. 


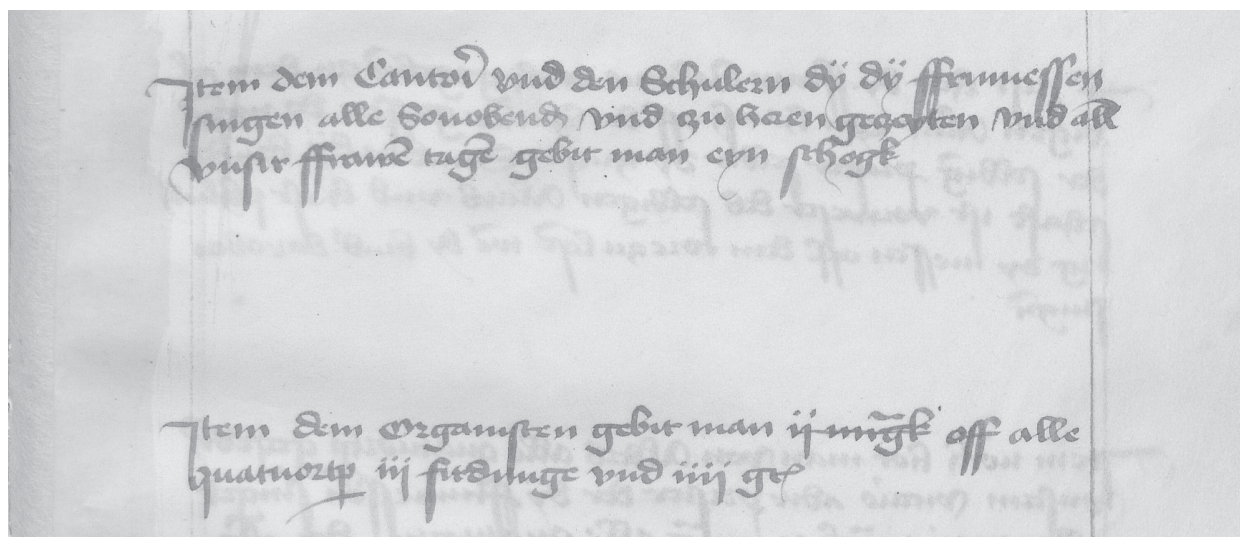

Il. I2. Biblioteka Jagiellońska, rkp. sygn. 2365 f. 7r: „[...] kantorowi i uczniom, którzy śpiewają podczas porannych mszy w każdą sobotę i święta maryjne daje się jeden ferton [wiardunk]. Również organiście daje się za każdy kwartał trzy fertony [wiardunki] i 4 grosze" ${ }^{\text {"65 }}$.

Zwraca uwagę dbałość o poziom tego śpiewu, co widać w niektórych zaleceniach statutu, jak np. w tym, by bracia „wspomożeni przez Pana wszystkim Władającego, przybywali do kaplicy [...] by odśpiewać melodie podczas mszy rzeczonego bractwa [...] i dla zbawienia ich samych, wedle zwyczaju i zgodnie ze wskazaniami dyrygujących, zaśpiewali pięknie, uroczyście i pobożnie, bez szemrania i bez jakichkolwiek przykrości i przeszkód ze strony innych braci”" ${ }^{66}$. Odnośnie do przymiotów wybieranego przez konfraternię prezbitera oczekiwano, że zwyczajowe msze „wraz z samymi braćmi będzie mógł odśpiewywać czystym głosem”'167. Śpiew był niezbędnym elementem nabożeństw, zatem bracia winni śpiewać „sami albo poprzez tych, których samo bractwo uzna za godnych wybrania” i dalej, że wigilie i msze za zmarłych „mają odśpiewać [sami] lub sprawić, że zostaną odśpiewane" ${ }^{168}$. Niewykluczone, że te wskazania dopuszczają możliwość udziału w nabożeństwach osób spoza konfraterni, być może szkolonych śpiewaków.

I65 Ferton (Ferding, Viertung) inaczej wiardunk (wiardunek, czwartak) - część grzywny równa I2 groszom. Zanotowane w tym źródle z końca XV w. wydatki brackie na organistę ( 3 fertony +4 grosze $=40$ groszy kwartalnie) były zatem niższe od kwot późniejszych ( $\mathrm{w}$ połowie XVI w. 8 florenów rocznie $=60$ groszy kwartalnie, zob. przyp. 80), a w końcu tego stulecia 66 groszy kwartalnie, zob.: E. Piwowarczyk, „Kościół Mariacki", op. cit., s. I59.

I66 „[... [ quod fratres in cantus melodÿs Domino omnia Regente ipsis coadiuvante decorati ad Missam dictae Fraternitatis $[\ldots]$ praefertur ad Capellam pronotatam decantandam [...] pro salute ipsorum iuxta modum et temperaturam regentium pulchre honorifice cum devotione sine murmure omnibusque aliorum Fratrum displicitis et impedimenta decantent" - na podstawie osiemnastowiecznej kopii aktu z I4II r.: ANK, sygn. 3362, p. 5. Podobny wydźwięk ma przytoczone przez Zaremską zalecenie dla konfratrów: „Qui sciunt cantare clara voce debent cantare, qui ignorant audire", zob.: H. Zaremska, op. cit., s. I22.

I67 „Presbyterum [...] qui missas [...] cum ipsis Fratribus poterit valeat decantare clara voce”, ANK 3362, p. 4. I68 „[...] per se aut quos ipsa Fraternitas duxerit eligendos [...]. Vigiliae [...] et in Crastino missam pro defunctis decantent aut faciant decantare", ibid., p. 5 . 


\section{KANTOR I SCHOLARZY}

Śpiew mianowanego przez rajców kantora i przygotowanych przez niego uczniów szkoły towarzyszył też niektórym częściom liturgii przed wielkim ołtarzem, a można to wnosić z późniejszego źródła - cytowanej już przy temacie organistów tzw. wizytacji Radziwiłłowskiej (zob. s. 2I). W raporcie z tej wizytacji przy określeniu obowiązków wikariuszy odnotowano, że nabożeństwa w dni świąteczne, niedziele, w wigilie świąt Najświętszej Marii Panny, a w adwencie i Wielkim Poście msze za zmarłych, odprawiane były ze śpiewem chłopców ${ }^{169}$. Do wskazanych tam również zadań kantora należał śpiew na porannej mszy i sumie w niedziele, święta i w wigilie świąt maryjnych oraz wielkopiątkowym responsorium, a ponadto - co już wyżej podano - w soboty i święta maryjne podczas uroczystych nabożeństw bractwa. Z raportu wynika ponadto, że naukę śpiewu pobierało wówczas u kantora czterech uczniów ${ }^{170}$; sto lat wcześniej mogło być ich więcej, skoro w statucie bractwa podano liczbę siedmiu (zob. il. II).

Jak wiadomo, w omawianym półwieczu funkcję kantora pełnił przez kilka lat Jerzy Liban ${ }^{171}$ i w ramach swych zadań mógł szkolić uczniów do wykonywania śpiewu figuralnego, co można wnioskować choćby z pewnej wzmianki w jego traktacie De accentuum ecclesiasticorum ${ }^{\mathrm{I72}}$. Piotr Poźniak, stawiając niegdyś pytanie, „kto i gdzie w Polsce miałby w latach dwudziestych czy trzydziestych XVI w. śpiewać utwory przeznaczone na zespół a voce piena”, wskazał właśnie (i tylko) Libana i jego uczniów, ale w kontekście polifonicznych przykładów z traktatów, a nie miejsca działalności ${ }^{173}$. Należy pamiętać, że rolą kantora było nie tylko nauczanie muzyki i przygotowanie scholarów do śpiewu, ale i przewodniczenie śpiewom liturgicznym ${ }^{\mathrm{I74}}$; na podstawie przytoczonych wyżej informacji źródłowych wypada przyjąć, że i w czasach Libana kantor mariacki łączył te funkcje. Można też przypuszczać, że monodia

169 E. Piwowarczyk, „Kościół Mariacki”, op. cit., s. I53.

I70 Ibid., s. I58. Niewykluczone, że scholarzy śpiewali też z kantorem podczas piątkowych komemoracji Męki Pańskiej (zob. s. 22).

I7I Był kantorem w l. I506-o9 (J. Krukowski, op. cit., s. I63), a później piastował stanowisko rektora szkoły (ludi magister - zob. il. I) - według Krukowskiego w 1 . od 1516 (lub I5I4) do I522 r. (op. cit., s. 86), według Elżbiety Witkowskiej-Zaremby w l. I5I4-28 („Liban Jerzy z Legnicy”, w: Encyklopedia Muzyczna PWM, red. Elżbieta Dziębowska, t. 5, Kraków 1997, s. 343).

I72 Jerzy Liban, Pisma o muzyce, opr. Elżbieta Witkowska-Zaremba, Kraków 1984 (= Monumenta Musicae in Polonia, seria C), s. IIz. Jest tu mowa o czterogłosowym opracowaniu wierszy Horacego i Boecjusza. Warto napomknąć, że w Archiwum Bazyliki Mariackiej zachował się inkunabuł Boetii Romani \& oratoris celeberrimi libri de consolatione philosophiae \& commentarius eximii preclarique doctoris sancti Thomae super eosdem incipiunt feliciter, [?Strassburg, Johann Pruss] I49I (ABMar, sygn. B4XV), w którym boecjańskie carmina opatrzono rękopiśmiennymi glosami z zapisem pojedynczych melodii. Ten znany mi od niedawna egzemplarz uzupełnia grupę innych z podobnymi glosami, o których pisałam w artykule poświęconym roli muzyki w ówczesnym nauczaniu zasad wersyfikacji, zob. Elżbieta Zwolińska, „Melodie z rozprawy Wawrzyńca Korwina Dialogus carmine \& soluta oratione conflatus i inne przykłady muzycznych komponentów humanistycznej sztuki wierszowania”, w: Ars musica and its contexts in medieval and early modern culture, red. Paweł Gancarczyk, Warszawa 2016, s. 87-103, o głosach na s. 94-98.

173 Piotr Poźniak, Repertuar polskiej muzyki wokalnej w epoce Renesansu, Kraków 1999, s. 202.

174 Zob.: R. Pośpiech, op. cit., s. I79. 
liturgiczna w kościele Mariackim była wówczas wykonywana zgodnie z wytycznymi przekazanymi w pismach magistra Jerzego, natomiast pytanie, czy edukacja muzyczna scholarów była ukierunkowana na śpiew polifoniczny podczas nabożeństw, pozostaje otwarte. Taka edukacja obejmowałaby prawdopodobnie tylko wybranych chłopców i młodzieńców; z treści wydanego drukiem przez Benedykta Herbesta w I559 r. programu szkoły Mariackiej wynika, że muzyce poświęcano tam tylko jedną godzinę w końcu tygodnia ${ }^{175}$.

Imiona innych mariackich kantorów/signatorów ${ }^{176} \mathrm{z}$ tego okresu można znaleźć w publikacjach Urbana i Krukowskiego, są tu jednak pewne różnice w zestawie nazwisk i dat. Urban wskazał kantorów Michała (I532-34) i Hieronima Friciusa (I547), signatora Stanisława (I549) i subsignatorów Macieja (I50I), Marcina z Radomska (I509), Walentego (I532) oraz Jana (I548) $)^{177}$, natomiast wykaz Krukowskiego obejmuje kantorów Jana z Bytomia (I5I6-I8), Michała z Kyrschen (I532-40), Marcina (I54I) ${ }^{178}$ i Hieronima Friciusa (I547), signatora Stanisława (I549) oraz subsignatorów Marcina z Radomska (I509), Walentego ze Zdżaru (I540), Jana (I548) i Wojciecha (I549) ${ }^{\text {179 }}$.

Brak mariackich źródeł z zapisem muzyki z I poł. XVI stulecia nie upoważnia do wnioskowania ex silentio, zwłaszcza że zachowane informacje o warunkach uprawiania tej sztuki pozwalają na ogólne wyobrażenie sfery dźwiękowej, otaczającej sprawowaną tam liturgię. Potrzeba podjęcia i kontynuowania tematu wydaje się oczywista - chodzi o miejsce o wyjątkowym znaczeniu religijnym i kulturowym: świątynię „o sylwecie zbliżonej raczej do katedry niż kościoła parafialnego” z „niebotycznymi i wyniosłymi wieżami” (jak je opisał Hartmann Schedel) ${ }^{180}$, ze wspaniałymi witrażami w ogromnych oknach prezbiterium i przede wszystkim z niezwykłą „Biblią z lipowego drewna” - bogatym w treści religijne retabulum Wita Stwosza, zawierającym wszak nie tylko sceny Zaśnięcia Marii, Wniebowzięcia i Koronacji ${ }^{18 \mathrm{I}}$. W tym prezbiterium rozlegał się - jak można przyjąć - codzienny śpiew mansjonarzy (o dobrych głosach) podczas liturgii godzin, mszy Salve Sancta parens, nabożeństw za żyjących

175 „Contextufinito, discende Musicae unam horam dari par est” („Właściwym jest, by [w soboty] po zakończeniu pracy poświęcić jedną godzinę na naukę muzyki”), zob.: Benedicti Herbesti Neapolitani, Cracoviensis scholae, apud S. Mariae templum, Institutio, Kraków I559 Mateusz Siebeneycher, f. Avv.

176 Zob. przyp. I52 i I6I.

177 W. Urban, „Kantorzy i sukcentorzy”, op. cit., s. 90.

178 Tę informację autor podaje tylko na podstawie Stownika Chybińskiego, gdzie brak odesłania do źródła, zob.:

J. Krukowski, op. cit., s. 163.

179 J. Krukowski, op. cit., s. I7I.

I80 Marcin Fabiański, „Przesławne miasto i drugi Rzym. Kraków i jego sztuka w oczach współczesnych w czasach największej świetności”, w: Urbs pulcherrima. Księga pamiątkowa na 750-lecie lokacji Krakowa, red. Andrzej Grzybkowski et al., Kraków 2008, s. 92, I25-I26.

I8I Wojciech Walanus, „Ołtarz Mariacki Wita Stwosza - arcydzieło sztuki późnego średniowiecza”, w: Biblia z lipowego drewna. Karty z dziejów Ottarza Mariackiego, red. Stanisław Waltoś, Kraków 2009, s. 29 i nast. 
i zmarłych dobroczyńców, a w nabożeństwach w ważniejszych dniach i porach kościelnego roku - śpiew kantora i muzykalnych scholarów; na drugim końcu kościoła odbywały się sobotnie i świąteczne spotkania religijne patrycjuszowskiej konfraterni z obowiązkowym (i dobrym) śpiewem ${ }^{\mathrm{I} 22}$; liturgię wzbogacały dźwięki organów, rozmieszczonych w dwóch lub trzech miejscach rozległego wnętrza. Sprawa muzyki organowej wymaga zresztą dodatkowego komentarza. Otóż historia muzyki staropolskiej pierwszej połowy XVI stulecia pozostaje pod znakiem traktatów i tabulatur, przy widocznym niedostatku źródeł z zapisem lokalnej twórczości w gatunku polifonii wokalnej, co prowadziło do szukania wzorców „hipotetycznych” - jak to określił Piotr Poźniak - ukrytych w przekazach instrumentalnych ${ }^{183}$. Obecnie uwaga badaczy przesuwa się w kierunku twórczości organowej, bowiem na podstawie ostatnio wydanej „szkoły kompozycji” Jana z Lublina (Ad faciendum cantum choralem) można sądzić, że w owym czasie zadanie polifonizacji melodii chorałowych należało do organisty $^{\mathrm{I} 84}$. W takim świetle udział organistów fary Mariackiej w uprawianiu polifonii instrumentalnej tworzonej na potrzeby liturgii wydaje się wysoce prawdopodobny, niemal oczywisty (niezależnie od stopnia trafności wysuniętej tu ostrożnie hipotezy o związkach samego Jana z Lublina z tym środowiskiem). W sferze pytań pozostaje natomiast uprawianie tam śpiewu figuralnego, chociaż trudno sobie wyobrazić, by w świątyni tej rangi, przynajmniej przy większych uroczystościach, gatunek ten nie był w ogóle obecny; w ważnych nabożeństwach mogli tu uczestniczyć muzycy z innych środowisk (w rachunkach miejskich z I553 r. jest wzmianka o muzykach królewskich ${ }^{185}$ ).

Józef M. Chomiński i Krystyna Wilkowska-Chomińska na kartach swej historii muzyki polskiej zwrócili uwagę, że szesnaste stulecie budziło tak duże zainteresowanie historyków muzyki, że „rozwój badań w tej dziedzinie tworzy sam w sobie własną historię cenną i ciekawą, choć niepozbawioną błędów, wahań, polemik"186. Można oczekiwać, że postawione tu nie bez wahań pytania o muzykę w świątyni Mariackiej w pierwszym półwieczu obecności tam dzieła Stwosza, będą przedmiotem weryfikacji, może polemiki, a przede wszystkim kontynuacji.

I82 O innych śpiewach wiernych parafii można wnosić z treści postanowień z lat trzydziestych XVI w. dotyczących kazań i śpiewów (podkr. E.Z.) po polsku w kościele farnym. Sprawy nie rozpoznałam dotychczas dokładnie, informację podaję z opisu dokumentu w: Katalog Archiwum Aktów Dawnych miasta Krakowa. I. Dyplomy pergaminowe, Kraków 1907, s. I42 i I43, poz. 530 i 532.

I83 P. Poźniak, Repertuar polskiej muzyki, op. cit., s. I05-I35, 202. Na takim „hipotetycznym” repertuarze opierała się wysunięta pół wieku temu przez Krystynę Wilkowską-Chomińską koncepcja krakowskiej szkoły kompozytorskiej, zob.: Krystyna Wilkowska-Chomińska, „Szkoła krakowska od końca XV do połowy XVI wieku”, Muzyka II (I966) nr 2, s. 54-67; tejże, Twórczość Mikotaja z Krakowa, Kraków 1967, s. 194-206; koncepcja upadła nie tylko z powodu zmian atrybucji utworów przypisywanych Mikołajowi z Krakowa, ale i krytycznego spojrzenia na zabieg rewokalizacji przekazów instrumentalnych, utożsamianej z docieraniem do rzekomego pierwowzoru.

I84 Zob.: E. Witkowska-Zaremba, „Wstęp”, op. cit., s. 22; G. Kos, op. cit., s. 44.

I85 ANK I6I5, p. I60: „Cantori dati sunt gr 30 Cum musicos Regios \& Domini Posznaniensis prandio excepisset qui pro festo Paschae eum P Templo iuvabant [?]".

I86 Józef M. Chomiński, Krystyna Wilkowska-Chomińska, Historia muzyki polskiej, cz. I, Kraków I995, s. 73. 


\section{QUESTIONS ABOUT MUSIC IN ST MARY'S CHURCH IN CRACOW IN THE FIRST HALF OF THE SIXTEENTH CENTURY AND THE ROLE OF JAN OF LUBLIN}

Gathering information about musical settings to liturgy celebrated in St Mary's Church in Cracow during the first decades after the completion of Veit Stoss's masterpiece altar is fraught with difficulties in the absence of strictly musical sources. However, documents preserved in Cracow archives: the National Archive, the Archive of the Metropolitan Curia, the Archive of St Mary's Basilica, and in the Jagiellonian Library throw some light on the conditions of performing music in this church. The article discusses such issues as the construction of the pipe organ, the activity of organists employed there, the singing duties imposed on the college of mansionaries and the cantor and his inferiors, and the activities of the patrician Brotherhood of the Holy Virgin Mary. Also, the author draws our attention to a mansionary and altarist named Jan of Lublin, offering a tentative hypothesis that he is to be identified with the owner and creator of one of the most important monuments of early Polish music: the organ Tablature of Jan of Lublin.

During this period, St Mary's Church was under the patronage of Cracow's municipal authorities, which paid the salaries of organists and cantors, supervised the finances of the mansionaries' college, as well as paid for the construction and maintenance of the pipe organ. As a result, the church was an excellent setting for integrating music and liturgy and the surviving records confirm that the instruments and the performers were taken care of. The analysis of this material made it possible to supplement and verify some facts or names, but the crucial questions are still a matter of speculation: the sources are not sufficient to determine whether singing - as an indispensable component of liturgy - was in this temple limited to chant monody, or whether figurative music sounded there on certain occasions, which would have been justified by the status of the church. It can only be speculated that the musical setting of liturgy consisted mainly of alternate singing and pipe organ performance within the framework of the then-current alternatim technique, in which the organist was responsible for the polyphonic arrangement of liturgical chants.

Translated by Pawet Gruchata

Słowa kluczowe/keywords: organy/organ, organista/organist, konfraternia/brotherhood, kantor/cantor, śpiew liturgiczny/liturgical chant, officium, Salve Sancta parens, polifonia instrumentalna/instrumental polyphony, patronat miejski/city patronage

Dr Elżbieta Zwolińska, muzykolog, w 1. 1967-2011 pracowała w Instytucie Muzykologii Uniwersytetu Warszawskiego; w kręgu jej zainteresowań naukowych dominuje muzyka staropolska okresu renesansu. e.m.zwolinska@uw.edu.pl 


\section{Nowe wydawnictwa Instytutu Sztuki PAN}

Bronisława Wójcik-Keuprulian. Korespondencja do Szwajcarii. Listy do Henryka Opieńskiego (1925-37) i Ludwika Bronarskiego (1929-38) opracowanie, wstep $i$ komentarze Matgorzata Sieradz. $\sim$

Zygmunt Mycielski - Andrzej Panufnik. Korespondencja

Część 2: Lata 1970-1987

opracowanie, wstep $i$ komentarze Beata Bolestawska-Lewandowska

\section{Archiwalne zeszyty „Muzyki”}

www.ispan.pl/pl/ wydawnictwa/crasopisma

iswydawnictwo@ispan.pl

\section{Studia Podyplomowe w Instytucie Sztuki Polskiej Akademii Nauk}

www.ispan.pl/pl/studia-podyplomowe

\section{Nowa seria wydawnicza Instytutu Sztuki PAN „Muzyka polska za granicą"}

Tom 1: Twórcy-źródła - archiwa

red. Beata Bolestanska-Lewandowska i Jolanta Gury-Pasiak. 